\section{Kastamonu Eğitim Dergisi Kastamonu Education Journal}

Eylül 2019 Cilt:27 Sayı:5

kefdergi.kastamonu.edu.tr
Başvuru Tarihi/Received: 02.12.2018

Kabul Tarihi/Accepted: 04.01.2019

DOI: $10.24106 /$ kefdergi.3451

\title{
Okul Öncesi Öğretmenlerinin Mesleki Tükenmişlik Düzeyleri ile Örgütsel Sinizm Tutumları Arasındaki İlişkinin İncelenmesi ${ }^{1}$
}

\section{Examination of Relationship between Preschool Teachers' Job Burnout Level and Organizational Cynicism Attitudes}

\section{Öz}

\author{
Sairan Mohammed Rashid MAHMOOD², Ramazan SAK ${ }^{3}$
}

Bu araşttrmanın amacı, okul öncesi öğretmenlerinin mesleki tükenmişlik düzeyleri ile örgütsel sinizm tutumları arasındaki ilişkinin incelenmesidir. Tarama modelindeki bu çalışmanın katılımcılarını, seçkisiz örnekleme yöntemiyle belirlenen 408 okul öncesi öğretmeni oluşturmuştur. Çalışmada, veri toplama araçları olarak Kişisel Bilgi Formu, Maslach Tükenmişlik Envanteri-Eğitimci Formu ve Örgütsel Sinizm Ölçeği kullanılmıştır. Araştırmanın veri analizinde bağımsız örneklemler için $t$ testi, Tek Faktörlü ANOVA ve Pearson korelasyon analizi gibi parametrik testler kullanılmıştr. Mesleki tükenmişliğin Duygusal Tükenme boyutu ve duyarsızlaşma boyutu ile örgütsel sinizmin kurumdan uzaklaşma, performansı düşüren etkenler, okula karşı olumsuz tutum, kararların alınmasına katılım boyutları ve sinizm ölçeğinin genel toplamı arasında pozitif yönde anlamlı bir ilişki bulunmuştur. Mesleki tükenmişliğin Kişisel Başarı boyutu ile örgütsel sinizmin kurumdan uzaklaşma, okula karşı olumsuz tutum, kararların alınmasına katlım boyutları ve sinizm ölçeğinin genel toplamı arasında negatif yönde anlamlı bir ilişki bulunmuştur. Mesleki tükenmişliğin Kişisel Başarı boyutu ile örgütsel sinizmin performansı düşüren etkenler boyutu arasında ise bir ilişki bulunmamıştır.

Anahtar Kelimeler: okul öncesi dönem, okul öncesi öğretmenleri, mesleki tükenmişlik, örgütsel sinizm, tutum.

\section{Abstract}

The aim of the present paper is to examine the relationship between preschool teachers' job-burnout levels and their organizational cynicism. Data for this quantitative study were collected using a survey of 408 current preschool teachers who were selected randomly. In addition to a Demographic Information Form, the data-collection tools included the Maslach Burnout Inventory - Educators Survey (MBI-ES) and the Organizational Cynicism Scale (OCS). Data were analyzed using independent-samples t-test, one-way ANOVA and Pearson's correlations. The researchers found positive correlation between the "emotional exhaustion", "depersonalization" sub-dimensions of the MBIES and, "alienation from employing organization", "factors decreasing performance", "negative attitudes toward school", "employee participation in decisions" sub-dimensions of the OCS and the OCS as a whole. There was a negative correlation between "personal accomplishment" sub-dimension of the MBI-ES and the entire OCS and its sub-dimensions "alienation from employing organization", "negative attitudes toward school", and "employee participation in decisions". However, there was no correlation between the MBI-ES' "personal accomplishment" sub-dimension and the OCS's "factors decreasing performance" sub-dimension.

Keywords: preschool period, preschool teachers, job burnout, organizational cynicism, attitude. 


\section{Extended Abstract}

Introduction: Though some prior research has focused on teachers' job burnout and the attitudes of 'organizational cynics' teaching at various grade levels, no such study has hitherto been based on data from preschools. Therefore, the aim of the present paper is to examine the relationship between preschool teachers' job-burnout levels and their organizational cynicism.

Methodology: Data for this quantitative study were collected using a survey of 408 current preschool teachers who were selected randomly. In addition to a Demographic Information Form, the data-collection tools included the Maslach Burnout Inventory - Educators Survey (MBI-ES), adapted into Turkish by Ince and Şahin (2015), and the Organizational Cynicism Scale (OCS) developed by Sağır and Oğuz (2012). Data were analyzed using independent-samples t-tests, one-way ANOVAs and Pearson's correlations.

Results: No statistically significant differences in the levels of teachers' burnout were associated with their gender, age, teaching experience, age groups taught, classroom size, or type of institution (i.e., an independent preschool vs. a preschool classroom in a primary school). However, statistically significant differences in their burnout levels were associated with both their working status (i.e., hourly paid vs. salaried) and their educational levels. In terms of organizational cynicism, the participants' OCS results - for all sub-dimensions as well as total scores - were not significantly differences with their ages, age groups taught, type of institution or teaching experience. However, there were statistically significant differences between the genders in both total OCS score and the OCS sub-dimension "factors decreasing performance". There were also statistically significant differences across educational level and working status in terms of the participants' scores on the OCS sub-dimensions "factors decreasing performan$\mathrm{ce}^{\prime \prime}$ and "alienation from employing organization" as well as their total OCS scores. Lastly, there was a statistically significant difference between class size and the OCS sub-dimension "factors decreasing performance". The researchers also found positive correlation between the "emotional exhaustion", "depersonalization" sub-dimensions of the MBI-ES and, "alienation from employing organization", "factors decreasing performance", "negative attitudes toward school", "employee participation in decisions" sub-dimensions of the OCS and the OCS as a whole. There was a negative correlation between "personal accomplishment" sub-dimension of the MBI-ES and the entire OCS and its sub-dimensions "alienation from employing organization", "negative attitudes toward school", and "employee participation in decisions". However, there was no correlation between the MBI-ES" "personal accomplishment" sub-dimension and the OCS's "factors decreasing performance" sub-dimension.

Discussion and Conclusion: This study's general findings related to the relationship between job burnout and organizational cynicism - i.e., that when the former increases the latter also increases - broadly support those of prior research conducted with teachers of older children: in particular, Simbula and Guglielmi (2010), who argued based on a 863 teachers, stated that cynicism should be considered a dimension of job burnout. Accordingly, the present study recommends a set of new regulations and practices aimed at reducing preschool teachers' job burnout as the best approach to reducing their organizational cynicism. 


\section{Giriş}

Bir bireyin bütün yaşamı göz önünde bulundurulduğunda, yaşamın bazı dönemlerinin bireyin fiziksel ve ruhsal gelişimleri açısından daha da kritik olduğu görülmektedir. 0-6 yaş aralığını kapsayan okul öncesi dönem, çocuğun kişilik gelişimi ve oluşumu, temel bilgi, beceri ve alışkanlıkların kazanılması ve yaşamın ileri yıllarına olan etkisinden dolayı oldukça kritik bir dönemdir (Akduman, 2012). Çocuğun bütün gelişim alanları (bilişsel, dil, fiziksel, sosyal ve duygusal) için güçlü bir zemin oluşturan, okul öncesi dönemde, çocuklara sunulacak uyarıcıların ve sağlanacak hizmetlerin onların bütün gelişim alanlarını desteklemesi açısından oldukça önemlidir (Essa, 2013; Morrison, 2011). Okul öncesi dönemin çocuğun gelişimi ve geleceği üzerindeki etkisi göz önünde bulundurulduğunda bu kademedeki çocuklar için ailenin, okul öncesi eğitim kurumlarının ve öğretmenlerin hayati bir role sahip oldukları görülmektedir.

Öğretmenlerin sahip oldukları mesleki ve kişilik özelliklerinin her eğitim kademesindeki çocuklar üzerinde oldukça önemli etkileri olmakla birlikle, ilk kez aile ortamından uzaklaşan ve yeni bir sosyal ortama giren okul öncesi çocukları için daha da önemli olduğu kabul edilmektedir (Koçyiğit, 2012). Okul öncesi öğretmeni, okul öncesi eğitimin amaçlarına ulaşılmasında önemli bir role sahip olmakla birlikte okul öncesi eğitim kurumlarının niteliğini belirleyen en önemli bir unsur olarak da kabul görmektedir (Koçyiğit, 2012). Bu nedenle okul öncesi öğretmenlerinin mesleki doyumlarının yüksek, mesleki tükenmişliklerinin düşük ve mesleklerine ilişkin olumlu duygulara sahip olmaları beklenmektedir.

Bazı meslek grupları tükenmişlik bağlamında diğer meslek gruplarına oranla daha büyük risk altındadırlar. Öğretim işi stresli işlerden biri olarak tanımlanmaktadır (Chaplain, 2008; Montgomery and Rupp, 2005). Öğretmenlerin görev ve sorumlulukları göz önünde bulundurulduğunda öğretmenlerin stres yaşamaları beklenen bir durumdur. Nitekim, Chan (2003) tarafindan yapılan çalışmada da öğretmenler mesleklerini yoğun stresli bir meslek olarak tanımlamışlardır. Stres ve tükenmişlik arasındaki ilişkiyi konu alan çalışmalarda da stres veren olayların tükenmişlik düzeyini etkilediği ortaya konulmuştur (Ergin, 1995; Sandıkçı, 2010). Öğretmenler yaşadıkları stres durumlarına bağlı olarak tükenmişlik duygusu hissedebilmektedirler.

Tükenmişlik kavramı farklı şekillerde tanımlanmıştr. Tükenmişlik Freudenberger tarafindan kişinin sahip olduğu enerji, güç ve kaynaklar üzerindeki yoğun talebin kişide başarısızlı̆a, yıpranmaya ve tükenmeye sebep olması olarak tanımlanmıştır (Freudenberger, 1974). Tükenmişlik iş yükünün fazlalı̆̆ı, gerekli desteğin yetersizliği, iş hayatındaki rol çatışmaları ve rol karmaşaları ile ilişkilendirilmektedir (Devilly, Wright ve Varker, 2009). Tükenmişlik mesleki doyuma ulaşamama ve gereğinden fazla strese maruz kalmanın sonucunda bireyin mesleğinden soğuması şeklinde de tanımlanmıştı (Cherniss, 1980). Diğer bir tanıma göre ise, mesleki tükenmişlik; iş yerindeki stres doğuran durumlara karşı bir tepki olarak uzun vadede ortaya çıkan psikolojik bir sendrom, çalışan ve işi arasındaki uyumsuzluğun sonucu olarak meydana gelen kronik bir gerginlik durumudur (Maslach, 2003). Duygusal Tükenme, duyarsızlaşma ve Kişisel Başarı olmak üzere üç boyutlu bir süreç olarak ele alınan Maslach'ın tükenmişlik modelinde; insanların psikolojik beklentilerine cevap olamayan çalışanlar ilk olarak Duygusal Tükenme yaşamaktadırlar. Aşırı iş taleplerine yetişemeyen çalışanlar hizmet verdikleri insanlara karşı mesafe alarak duyarsızlaşmakta ve son olarak da toplumun ve çalıştıları kurumun beklentilerine cevap olamadıklarını, beklentiler ve kendi davranışları arasındaki çelişkiyi fark ederek Kişisel Başarılarının yetersiz olduğunu düşünmektedirler (Maslach ve Jackson, 1981).

Maslach ve Jackson (1981) ve Maslach, Schaufeli ve Leiter (2001) tükenmişliğin bir bileşeni olarak sinizmi vurgulamış ve sinizmi bireyin işinin çeşitli yönlerine karşı negatif, duyarsız veya son derece bağımsız bir tepki olarak tanımlamışlardır. Örgütsel sinizm ise farklı şekillerde tanımlanmaktadır. Örneğin, Dean, Brandes ve Dharwadkar’a göre (1998) örgütsel sinizm, bireyin çalıştğı örgütün doğruluk veya dürüstlükten yoksun olduğuna dair bir inancı, örgüte yönelik negatif duyguları ve örgüte yönelik inançlar ve duygulardan oluşan kötüleyici (aşağılayıcı, küçümseyici) ve eleştirici eğilimleri kapsayan üç bileşenden oluşan negatif bir tutumdur. Sinizmin bilişsel, duyuşsal ve davranışsal olmak üzere üç boyutu bulunmaktadır (Dean, Brandes ve Dharwadkar, 1998). Bilişsel boyutta, sinik kişiler örgütte kendilerine ihanet edildiğini çünkü adalet, dürüstlük ve samimiyet gibi özelliklerden yoksun olunduğunu belirtmektedirler (Kutanis ve Dikili, 2010). Örgütsel sinizmin duyuşsal boyutunda saygısızlık, kendini beğenmişlik, karşındakini küçük görmek, nefret, utanç duygusu, güvensizlik ve hayal kırıklığı gibi duygular yer alabilmektedir (Çalışkan, 2016). Davranışsal boyutunda ise şikâyette bulunma, dalga geçme, eleştirilerde bulunma, çalışanların birbirleriyle anlamlı bakışmaları, birbirlerine sırıtmaları ve birbirlerini küçümser bir şekilde gülümsemeleri gibi birtakım davranışlar yer almaktadır (Yalçın, 2017). Örgütsel sinizm kısaca, çalışanların bulundukları örgüte karşı olumsuz tutumları olarak tanımlanmaktadır.

Örgütsel sinizmi tükenmişliğin boyutlarından biri olarak tükenmişliğin diğer boyutlarıyla birlikte inceleyen çalışmalar bulunmaktadır (Lorente, Salanova, Martinez ve Schaufeli, 2008; Salanova, Llorens, Garcia-Renedo, Burriel, Breso ve Schoufeli, 2005; Simbula ve Guglielmi, 2010). Bu şekilde sinizmi tükenmişliğin bir boyutu olarak ele alan çalışmalar 
ulaşılabildiği kadarıyla sadece üç çalışmadan ibarettir. Ancak, örgütsel sinizmi mesleki tükenmişlikten bağımsız olarak ele alan çalışmalar (Altınkurt ve Yılmaz, 2016; Atmaca, 2014; Bölükbaşıoğlu, 2013; Çanak, 2014; Ergen, 2015; Demirel, 2015; Karademir, 2016; Karadağ, Kılıçoğlu ve Yılmaz, 2014; Kılıç, 2013; Kılıç, 2011; Yüksel, 2015; Polat, 2014; Polatcan, 2012; Özcan, 2014; Özer, 2014; Uzun, 2015; Yıldııım, 2015; Şirin, 2011) ile mesleki tükenmişlik ve örgütsel sinizm arasındaki ilişkiyi inceleyen çalışmalar (Amasralı, 2016; Gün ve Atanur Baskan, 2017; Koç, 2015) oldukça fazladır. Okul öncesi öğretmenlerinin mesleki tükenmişlik düzeylerini çeşitli değişkenlere göre inceleyen çalışmalar da söz konusudur (Acar, 2016; Akman, Taşkın, Özden ve Çörtü, 2010; Deniz Kan, 2008; Gürbüz, 2008; Kapıkıran, 2003; Şenel ve Buluş, 2016; Tuğrul ve Çelik, 2002; Yaşar Ekici, 2017; Yıldız ve Uzum, 2018).

İlgili alanyazın incelendiğinde farklı kademelerdeki öğretmenlerin mesleki tükenmişlikleri ile örgütsel sinizm tutumlarını inceleyen çalışmalar (Amasralı, 2016; Koç, 2015) bulunmakla birlikte okul öncesi öğretmenlerinin mesleki tükenmişlik ve örgütsel sinizm tutumlarını inceleyen bir çalışmaya rastlanılmamıştır. Okul öncesi eğitimin niteliğini belirleyen önemli unsurlardan biri olan öğretmenlerin mesleki tükenmişlik düzeyleri ve örgütsel sinizm tutumlarının belirlenmesi bu kademedeki öğretmenlerin görev ve sorumluluklarını ne kadar nitelikli bir şekilde yerine getirdiklerinin de bir göstergesidir. Bununla birlikte, okul öncesi öğretmenlerinin mesleki tükenmişlik ve örgütsel sinizm tutumlarının belirlenmesi, okul öncesi öğretmenlerinin mesleklerine ilişkin algı ve tutumları hakkında daha gerçekçi bir fikir vermesi beklenmektedir.

Bu araştırmanın genel amacı, okul öncesi öğretmenlerinin mesleki tükenmişlik düzeyleri ile örgütsel sinizm tutumları arasındaki ilişkinin incelenmesidir. Bu amaç doğrultusunda aşağıdaki problem cümlesine cevap aranmıştır:

Okul öncesi öğretmenlerinin mesleki tükenmişlik düzeyleri ile örgütsel sinizm tutumları arasında anlamlı bir ilişki var mıdır?

Araştırmada ayrıca aşağıda verilen alt sorulara yanıt bulmaya çalışılmıştır:

1. Okul öncesi öğretmenlerinin mesleki tükenmişlik düzeyleri;

1.1. Cinsiyetlerine,

1.2. Yaşlarına,

1.3. Kıdemlerine,

1.4. Öğrenim düzeylerine,

1.5. Kurumdaki çalışma durumlarına,

1.6. Eğitim verilen yaş grubuna,

1.7. Çalışılan kurum türüne ve

1.8. Sınıftaki çocuk sayısına göre farklılaşmakta mıdır?

2. Okul öncesi öğretmenlerinin örgütsel sinizm tutumları;

2.1. Cinsiyetlerine,

2.2. Yaşlarına,

2.3. Kıdemlerine,

2.4. Öğrenim düzeylerine,

2.5. Kurumdaki çalışma durumlarına,

2.6. Eğitim verilen yaş grubuna,

2.7. Çalışılan kurum türüne ve

2.8. Sınıftaki çocuk sayısına göre farklılaşmakta mıdır?

3. Okul öncesi öğretmenlerinin mesleki tükenmişlik düzeyleri ile örgütsel sinizm tutumları arasında anlamlı bir ilişki var mıdır?

\section{Yöntem}

\section{Araşttrma modeli}

Bu araştırmada, okul öncesi öğretmenlerinin mesleki tükenmişlik düzeyleri ile örgütsel sinizm tutumları arasındaki ilişkinin incelenmesi amacıyla ilişkisel tarama modeli kullanılmıştır. Tarama modelleri, bir durumu var olduğu şekliyle betimlemeyi amaçlayan araştırma yaklaşımları olarak açıklanmaktadır (Karasar, 2005). ílişkisel tarama tipi araştırmalarda iki değişken arasında belirlenen ilişki, iki değişkenden birinde gözlenen değişimin bir kısmının diğer değişkenden kaynaklanabileceğini göstermektedir (Can, 2016). Diğer bir ifadeyle, ilişkisel tarama modelinde, değişkenlerin birlikte değişip değişmediği; şayet bir değişmenin olması durumunda ise bu değişimin nasıl olduğu saptanmaya çalışılmaktadır (Karasar, 2005). Bu çalışmada okul öncesi öğretmenlerinin mesleki tükenmişlik düzeyleri ile örgütsel sinizm tutumları

| Kastamonu Eğitim Dergisi, 27(5), 2019| 
arasındaki ilişkinin incelenmesi amacıyla, okul öncesi öğretmenlerinin mevcut durumlarında herhangi bir değişikliğe, uygulamaya ve müdahaleye yer verilmeden olduğu şekliyle incelenmesi amaçlandığından, bu çalışma ilişkisel tarama modelinde dizayn edilmiş bir çalışmadır.

\section{Evren ve örneklem}

Bir çalışmanın evreni, soruları cevaplamak için ihtiyaç duyulan verilerin elde edildiği canlı ya da cansız varlıklardan oluşan büyük gruptur (Büyüköztürk, Çakmak, Kılıç, Akgün, Karadeniz ve Demirel, 2014). Bu araştırmanın evrenini, Van ilinde okul öncesi eğitim kurumlarında (resmi ve özel bağımsız anaokulları, ilkokullara bağlı anasınıfları) görev yapan okul öncesi öğretmenlerinin tamamı oluşturmaktadır. Örneklem, belli kurallara göre evrenden seçilen ve seçildiği evreni temsil yeterliği kabul edilen küçük kümedir (Karasar, 2005). Bu araştırmada Basit Seçkisiz Örnekleme yöntemi kullanılmıştır. Seçkisiz örnekleme yöntemlerinin temel özelliği, örnekleme birimlerinin örnekleme seçilme olasılıklarının eşit ve bağımsız olmasından dolayı örneklemin evreni temsil etme gücünün yüksek olmasıdır (Büyüköztürk, Kılıç, Çakmak, Akgün, Karadeniz ve Demirel, 2014). Bu araştırmanın örneklemini, Van ilinde okul öncesi eğitim kurumlarında görev yapan ve seçkisiz örnekleme yöntemiyle belirlenen 408 okul öncesi öğretmeni oluşturmuştur.

Araştırmaya katılan okul öncesi öğretmenlerinin \%89.2'sini kadın okul öncesi öğretmenleri oluşturmuşken, \%10,8'ini erkek okul öncesi öğretmenleri oluşturmuştur. Öğretmenlerin \%22.8'i 24 ve alt yaş aralığında, \%44.9'u 25-29 yaş aralığında, \%23'ü 30-34 yaş aralığında ve \%9.3'ü 35 ve üstü yaş aralığındadır. Okul öncesi öğretmenlerinin \%58.8'i 4 yıl ve alt, \%31.1'i 5-9 yıl aralığında ve \%10'u 10 yıl ve üzeri kıdeme sahiptir.

Çalışmaya katılan okul öncesi öğretmenlerinin \%17.2'si ön lisans mezunu iken, \%82.8'i lisans mezunudur. Öğretmenlerin \%77.2'si kadrolu olarak çalışırken, \%22.8'i ücretli olarak çalışmaktadır. Okul öncesi öğretmenlerinin \%9.8'i 3 yaş grubuna, \%25.2'si 4 yaş grubuna, \%39'u 5 yaş grubuna, \%14.5'i 6 yaş grubuna ve \%11.5'i ise karma yaş grubuna eğitim vermektedir. Okul öncesi öğretmenlerinin \%52.7'si bağımsız anaokullarında çalışırken, \%47.3'ü anasınıflarında çalışmaktadır. Bu çalışmaya katılan okul öncesi öğretmenlerinin \%22.3'ünün sınıflarında 11-15 aralığında, \%40'ının sınıflarında 16-20 aralığında, \%26.5'inin sınıflarında 21-25 aralığında ve \%11.3'ünün sınıflarında ise 26-30 aralığında çocuk bulunmaktadır. Okul öncesi öğretmenlerinin \%75.7'si son 1 yılda meslekleriyle ilgili herhangi bir eğitime/etkinliğe katılmadıklarını belirtmişken, \%24.3'i son 1 yılda meslekleriyle ilgili bir eğitime/etkinliğe katıldıklarını belirtmişlerdir.

\section{Veri toplama araçları}

Bu araştrrmada, Kişisel Bilgi Formu, Maslach Tükenmişlik Envanteri-Eğitimci Formu (İnce ve Şahin, 2015) ve Örgütsel Sinizm Ölçeği (Sağır ve Oğuz, 2012) kullanılmıştır.

\section{Kişisel Bilgi Formu}

Araştırmada kullanılan kişisel bilgi formu araştırmacılar tarafindan hazırlanmıştır. Kişisel bilgi formunun hazırlanma sürecinde araştırma konusuyla ilgili yapılmış çalışmalar incelenmiş ve bazı değişkenlere ilişkin daha önce kullanılmış sorulardan yararlanmıştır. Yaş, cinsiyet, mesleki kıdem, öğrenim düzeyi, mezun olunan lisans programının adı, çalışma durumu (Kadrolu/ücretli), eğitim verilen yaş grubu, çalışılan kurum türü (Bağımsız anaokulu, anasınıf, uygulama sınıf), sınıftaki çocuk sayısı ve son bir yılda mesleklerine yönelik eğitim alma durumuna yönelik kapalı uçlu sorular yer almaktadır.

\section{Maslach Tükenmişlik Envanteri-Eğitimci Formu}

Bu araştırmada kullanılan Maslach Tükenmişlik Envanteri-Eğitimci Formu, Maslach Tükenmişlik Envanteri'nin Maslach, Jackson ve Schwab tarafindan bazı değişiklikler yapılarak düzenlendiği eğitimci formu olup, İnce ve Şahin (2015) tarafindan Türkçe'ye uyarlanmıştır. Ölçek, 7'li likert tipi olup 22 maddeden oluşmaktadır. Ölçek üç boyuttan oluşmakta olup, Duygusal Tükenme boyutunda 9 madde $(1,2,3,6,8,13,14,16,20)$, Duyarsılaşma boyutunda 5 madde $(5,10$, $11,15,22)$ ve Kişisel Başarı boyutunda 8 madde $(4,7,9,12,17,18,19,21)$ yer almaktadır. Envanterde yer alan boyutlar ayrı ayrı puanlanmaktadır. Maddelerden alınabilecek en düşük puan " 0 ", en yüksek puan ise " 6 " dır. Seçeneklerin puanlaması ise şu şekildedir: "Hiçbir zaman-0", "Yılda birkaç kez-1", "Ayda bir kez-2", "Ayda birkaç kez-3", "Haftada bir kez-4", "Haftada birkaç kez-5" ve "Her gün-6". Ölçeğin puanlama anahtarı incelendiğinde Duygusal Tükenme boyutunda alınabilecek en yüksek puan 54, Kişisel Başarı boyutunda 48, duyarsızlaşma boyutunda ise 30 puandır. Kişisel Başarı boyutunda alınan yüksek puanların karşılığı düşük düzeyde yaşanan tükenmişliktir. Bir başka ifade ile bu boyutta düşük puan alan çalışanlar yüksek düzeyde tükenmişlik yaşamaktadır. Kişisel Başarı boyutunun puanlanması ve yorumlanması arasındaki ters yönlü iliş̧iden dolayı bu boyutu Kişisel Başarısızlık hissi veya azalan Kişisel Başarı olarak niteleyen araştırmacılar bulunmaktadır (İnce, 2014: 88). Ölçeğin güvenilirliğine iç tutarlılık yöntemi ile bakılmıştı. Cronbach Alpha formülü ile hesaplanan iç tutarlılık katsayısı her bir alt boyut için ayrı ayrı hesaplanmıştır. İnce ve Şahin (2015) tarafindan Duygusal Tükenme boyutu için Cronbach Alpha katsayısı .88, Duyarsılaşma boyutu için .78 ve Kişisel Başarı boyutu için .74 olarak hesaplanmıştır. Bu çalışmada ise Duygusal Tükenme boyutu için Cronbach Alpha katsayısı .82, Duyarsızlaşma boyutu için .74 ve Kişisel Başarı boyutu için .70 olarak hesaplanmıştır. 


\section{Örgütsel Sinizm Ölçeği (ÖSÖ)}

Bu araştırmada Sağır ve Oğuz (2012) tarafindan geliştirilen öğretmenlere yönelik Örgütsel Sinizm Ölçeği kullanılmıştr. Ölçek dört alt boyuttan (1- Çalıştı̆ı kurumdan (duyuşsal ve davranışsal) uzaklaşma, 2- Performansı düşüren etkenler, 3-Okula karşı olumsuz tutum, 4- Çalışanların kararlara/uygulamalara katılımı) ve toplamda 25 maddeden oluşmaktadır. Sağır ve Oğuz (2012) tarafindan yapılan faktör analizleri sonucunda her bir alt boyut şu şekildedir.

1- Çalıştğı kurumdan (duyuşsal ve davranışsal) uzaklaşma: Bu alt boyut toplamda 7 maddeden $(22,23,25,24,19$, $9,5)$ oluşmaktadır. Bu maddeler toplam varyansın \% 38'ini açıklamaktadırlar.

2- Performansı düşüren etkenler: Bu alt boyut toplamda 9 maddeden $(7,8,11,16,4,15,18,6$, 17) oluşmaktadır. Bu maddeler toplam varyansın \% 8'ini açıklamaktadırlar.

3- Okula karşı olumsuz tutum: Bu alt boyut toplamda 5 maddeden $(10,12,13,14,20)$ oluşmaktadır. Bu maddeler toplam varyansın \% 8'ini açıklamaktadırlar.

4- Çalışanların kararlara/uygulamalara katılımı: Bu alt boyut toplamda 4 maddeden $(1,2,3,21)$ oluşmaktadır. Bu maddeler toplam varyansın \% 5'ini açıklamaktadırlar. Bu boyuttaki maddeler ters puanlanan maddelerdir.

Yukarıdaki bu dört faktör toplam varyansın \%59'unu açıklamaktadır. Sağır ve Oğuz (2012) tarafindan Cronbach Alfa iç tutarlılık güvenirlik katsayısı birinci faktör için .86, ikinci faktör için .88, üçüncü faktör için .85, dördüncü faktör için .68 ve ölçeğin genel toplamı için .89 olarak hesaplanmıştır. Bu çalışmada ise Cronbach Alfa iç tutarlılık güvenirlik katsayısı birinci faktör için .84, ikinci faktör için .90, üçüncü faktör için .77, dördüncü faktör için .68 ve ölçeğin genel toplamı için .91 olarak hesaplanmıştır. Beşli likert tipi olan Örgütsel Sinizm Ölçeği'nin her bir maddesine katlımcıların Kesinlikle Katılıyorum'dan Kesinlikle Katılmıyorum'a doğru olan beş seçenekten kendilerine uygun olanı işaretlemeleri beklenmektedir. Örgütsel Sinizm Ölçeğinden alınabilecek puanlar 25 ile 125 arasında değişmektedir. Ölçekten alınacak yüksek puanlar öğretmenlerin çalıştkları kuruma ilişkin olumsuz tutumlarının yüksek oluşunun bir göstergesidir (Sağır ve Oğuz, 2012).

\section{Verilerin işlenişi ve analizi}

Toplanan veriler analize dâhil edilmeden önce uygun doldurulma durumları (cevapsız bırakılma ya da aynı maddenin birden çok işaretlenmesi) açısından gözden geçirilmiş, eksikleri bulunan 34 ölçek değerlendirmeye alınmamıştr. Veri toplama araçlarından elde edilen veriler SPSS 22 istatistik paket programına aktarılarak verilerin analizi ve yorumlanması yapılmıştır. Çalışmaya katılan okul öncesi öğretmenlerinin demografik ve mesleki durumlarına ilişkin veriler için frekans ve yüzdelik dağılımlar gibi betimsel istatistikler hesaplanmıştır. Veri analizinde kullanılacak testlere karar vermek için araştırmada elde edilen verilerin normal dağılım gösterip göstermediğini test etmek için Kolmogorow-Smirnow testi kullanılmıştır. Kolmogorow-Smirnow testinin sonucuna göre ölçekten elde edilen puanların normal dağıım göstermesinden $(n=408, p>.05)$ dolayı parametrik testler kullanılmıştı. Bu nedenle verilerin analizinde; iki gruptan oluşan değişkenleri karşılaştırmak için için bağımsız örneklemler için t testi, ikiden fazla gruptan oluşan değişkenleri karşılaştırmak için Tek Yönlü Varyans Analizi (ANOVA) ve değişkenler arasındaki ilişkiyi incelemek için Pearson Çarpım Moment Korelasyon Analizi kullanılmıştır. Anlamlılık düzeyi olarak 0.05 veya 0.01 kabul edilmiştir.

\section{Bulgular}

\section{Okul öncesi öğretmenlerinin mesleki tükenmişlik düzeyleri cinsiyetlerine göre farklılaşmakta mıdır?}

Okul öncesi öğretmenlerinin mesleki tükenmişlik düzeylerinin cinsiyetlerine göre farklılaşıp farklılaşmadığını belirlemek için yapılan bağımsız örneklemler için $\mathrm{t}$ testi sonucunda; Duygusal Tükenme boyutunda $\left(\mathrm{t}_{406}=-1,875, \mathrm{p}>.05\right)$, duyarsızlaşma boyutunda $\left(\mathrm{t}_{406}=-, 418, \mathrm{p}>.05\right)$ ve Kişisel Başarı boyutunda $\left(\mathrm{t}_{406}=-, 355, \mathrm{p}>.05\right)$ aradaki farkın anlamlı olmadığı bulunmuştur.

\section{Okul öncesi öğretmenlerinin mesleki tükenmişlik düzeyleri yaşlarına göre farklılaşmakta mıdır?}

Okul öncesi öğretmenlerinin mesleki tükenmişlik düzeylerinin yaşlarına göre anlamlı olarak farklılaşıp farklılaşmadığını belirlemek için yapılan Tek Faktörlü ANOVA sonucunda; Duygusal Tükenme boyutunda $\left(F_{404}=1,996, p>.05\right)$, duyarsızlaşma boyutunda $\left(F_{404}=1,661, p>.05\right)$ ve Kişisel Başarı boyutunda $\left(F_{404}=1,979, p>.05\right)$ aradaki farkın anlamlı olmadığı bulunmuştur.

\section{Okul öncesi öğretmenlerinin mesleki tükenmişlik düzeyleri kıdemlerine göre farklılaşmakta mıdır?}

Okul öncesi öğretmenlerinin mesleki tükenmişlik düzeylerinin kıdemlerine göre anlamlı olarak farklılaşıp farklılaşmadığını belirlemek için yapılan Tek Faktörlü ANOVA sonucunda; Duygusal Tükenme boyutunda $\left(F_{405}=, 211, p>.05\right)$, duyarsılaşma boyutunda $\left(F_{405}=1,053, p>.05\right)$ ve Kişisel Başarı boyutunda $\left(F_{405}=1,192, p>.05\right)$ aradaki farkın anlamlı olmadığı bulunmuştur. 
Okul öncesi öğretmenlerinin mesleki tükenmişlik düzeyleri öğrenim düzeylerine göre farklılaşmakta mıdır?

Tablo 1. Okul Öncesi Öğretmenlerinin Mesleki Tükenmişlik Ölçeği Puanlarının Öğrenim Düzeylerine Göre T Testi Sonuçları

\begin{tabular}{|c|c|c|c|c|c|c|}
\hline & $\begin{array}{l}\text { Öğrenim } \\
\text { Düzeyi }\end{array}$ & $\mathbf{N}$ & $\bar{x}$ & S.s & $\mathbf{t}$ & $\mathbf{p}$ \\
\hline \multirow{2}{*}{ Duygusal Tükenme } & Ön lisans & 70 & 11,27 & 7,95 & \multirow{2}{*}{$-4,044$} & \multirow{2}{*}{000} \\
\hline & Lisans & 338 & 16,17 & 9,47 & & \\
\hline \multirow{2}{*}{ Duyarsızlaşma } & Ön lisans & 70 & 1,88 & 3,14 & \multirow{2}{*}{$-3,106$} & \multirow{2}{*}{,002 } \\
\hline & Lisans & 338 & 3,77 & 4,87 & & \\
\hline \multirow{2}{*}{ Kişisel Başarı } & Ön lisans & 70 & 40,07 & 6,57 & \multirow{2}{*}{2,734} & \multirow{2}{*}{,007 } \\
\hline & Lisans & 338 & 37,51 & 7,21 & & \\
\hline
\end{tabular}

Tablo 1 incelendiğinde, Duygusal Tükenme boyutunda $\left(t_{406}=-4,044, p<05\right)$, duyarsızlaşma boyutunda ( $t_{406}=-3,106$, $\mathrm{p}<05)$ ve Kişisel Başarı boyutunda $\left(\mathrm{t}_{406}=2,734, \mathrm{p}<05\right)$ aradaki farkın anlamlı olduğu bulunmuştur. Duygusal Tükenme boyutunda lisans mezunu okul öncesi öğretmenlerinin ortalamalarının ( $\bar{X}=16,17)$ ön lisans mezunu okul öncesi öğretmenlerin ortalamalarından $(\bar{X}=11,27)$ daha yüksek olduğu görülmektedir. Duyarsızlaşma boyutunda lisans mezunu okul öncesi öğretmenlerinin ortalamalarının $(\bar{X}=3,77)$ ön lisans mezunu okul öncesi öğretmenlerin ortalamalarından $(\bar{X}=1,88)$ daha yüksek olduğu görülmektedir. Kişisel Başarı boyutunda ise lisans mezunu okul öncesi öğretmenlerinin ortalamalarının $(\bar{X}=37,51)$ ön lisans mezunu okul öncesi öğretmenlerin ortalamalarından $(\bar{X}=40,07)$ daha düşük olduğu görülmektedir.

Okul öncesi öğretmenlerinin mesleki tükenmişlik düzeyleri kurumdaki çalışma durumlarına göre farklılaşmakta mıdır?

Tablo 2. Okul Öncesi Öğretmenlerinin Mesleki Tükenmişlik Ölçeği Puanlarının Çalışma Durumlarına Göre T Testi Sonuçları

\begin{tabular}{lcccccc}
\hline & $\begin{array}{c}\text { Çalışma } \\
\text { Durumu }\end{array}$ & $\mathbf{N}$ & $\overline{\mathbf{X}}$ & $\mathbf{S . s}$ & $\mathbf{t}$ & $\mathbf{p}$ \\
\hline \multirow{2}{*}{ Duygusal Tükenme } & Kadrolu & 315 & 16,21 & 9,67 & \multirow{2}{*}{3,512} & \multirow{2}{*}{000} \\
\hline \multirow{2}{*}{ Duyarsızlaşma } & Ücretli & 93 & 12,36 & 7,77 & & \\
& Kadrolu & 315 & 3,79 & 4,89 & \multirow{2}{*}{2,742} & \multirow{2}{*}{006} \\
\hline \multirow{2}{*}{ Kişisel Başarı } & Ücretli & 93 & 2,29 & 3,59 & & \multirow{2}{*}{003} \\
\hline
\end{tabular}

Tablo 2 incelendiğinde, Duygusal Tükenme boyutunda $\left(\mathrm{t}_{406}=3,512, \mathrm{p}<05\right)$, duyarsılaşma boyutunda $\left(\mathrm{t}_{406}=2,742\right.$, $\mathrm{p}<05)$ ve Kişisel Başarı boyutunda $\left(\mathrm{t}_{406}=-2,943, \mathrm{p}<05\right)$ aradaki farkın anlamlı olduğu bulunmuştur. Duygusal Tükenme boyutunda kadrolu çalışan okul öncesi öğretmenlerinin ortalamalarının $(\bar{X}=16,21)$ ücretli olarak çalışan okul öncesi öğretmenlerin ortalamalarından $(\bar{X}=12,36)$ daha yüksek olduğu görülmektedir. Duyarsızlaşma boyutunda kadrolu okul öncesi öğretmenlerinin ortalamalarının $(\bar{X}=3,79)$ ücretli olarak çalışan okul öncesi öğretmenlerin ortalamalarından $(\bar{X}=2,29)$ daha yüksek olduğu görülmektedir. Kişisel Başarı boyutunda ise kadrolu okul öncesi öğretmenlerinin ortalamalarının $(\bar{X}=37,39)$ ücretli olarak çalışan okul öncesi öğretmenlerin ortalamalarından $(\bar{X}=39,86)$ daha düşük olduğu görülmektedir. Bu boyutta düşük puan alan çalışanlar yüksek düzeyde tükenmişlik yaşadıklarından dolayı, kadrolu okul öncesi öğretmenlerinin ücretli olarak çalışan öğretmenlerden daha fazla Kişisel Başarısızlık yaşadıkları görülmektedir.

Okul öncesi öğretmenlerinin mesleki tükenmişlik düzeyleri eğitim verilen yaş grubuna göre farklılaşmakta mıdır?

Okul öncesi öğretmenlerinin mesleki tükenmişlik düzeylerinin eğitim verilen yaş grubuna göre farklılaşıp farklılaşmadığını belirlemek için yapılan Tek Faktörlü ANOVA sonucunda; okul öncesi öğretmenlerinin duygusal tükenmişlik düzeylerinin $\left(F_{403}=, 725, p>.05\right)$, duyarsılaş̧ma düzeylerinin $\left(F_{403}=1,174, p>.05\right)$ ve Kişisel Başarı boyutunda tükenmişlik düzeylerinin $\left(F_{404}=1,339, p>.05\right)$ anlamlı bir farklılık göstermediği bulunmuştur.

\section{Okul öncesi öğretmenlerinin mesleki tükenmişlik düzeyleri çalışılan kurum türüne göre farklılaşmakta mıdır?}

Okul öncesi öğretmenlerinin mesleki tükenmişlik düzeylerinin çalıştıkları kurum türüne göre farklılaşıp farklılaşmadığını belirlemek için yapılan bağımsız örneklemler için $t$ testi sonucunda; Duygusal Tükenme boyutunda $\left(t_{406}=-1,543\right.$, $p>.05)$, duyarsızlaşma boyutunda $\left(t_{406}=-, 730, p>.05\right)$ ve Kişisel Başarı boyutunda $\left(t_{406}=1,573, p>.05\right)$ aradaki farkın anlamlı olmadığı bulunmuştur. 
Okul öncesi öğretmenlerinin mesleki tükenmişlik düzeyleri sınıftaki çocuk sayısına göre farklılaşmakta mıdır?

Okul öncesi öğretmenlerinin mesleki tükenmişlik düzeylerinin sınıftaki çocuk sayısına göre farklılaşıp farklılaşmadığını belirlemek için yapılan Tek Faktörlü ANOVA sonucunda; Duygusal Tükenme boyutunda $\left(F_{404}=1,319, p>05\right)$, duyarsızlaşma boyutunda $\left(\mathrm{F}_{404}=, 481, \mathrm{p}>.05\right)$ ve Kişisel Başarı boyutunda $\left(\mathrm{F}_{404}=, 543, \mathrm{p}>.05\right)$ aradaki farkın anlamlı olmadığı bulunmuştur.

Okul öncesi öğretmenlerinin örgütsel sinizm tutumları cinsiyetlerine göre farklılaşmakta mıdır?

Tablo 3. Okul Öncesi Öğretmenlerinin Örgütsel Sinizm Ölçeği Puanlarının Cinsiyetlerine Göre T Testi Sonuçları

\begin{tabular}{|c|c|c|c|c|c|c|}
\hline & Cinsiyet & $\mathbf{N}$ & $\bar{x}$ & S.s & $\mathbf{t}$ & $\mathbf{p}$ \\
\hline \multirow{2}{*}{$\begin{array}{l}\text { Kurumdan (Duyuşsal ve davranış- } \\
\text { sal) uzaklaşma }\end{array}$} & Kadın & 364 & 15,19 & 5,55 & \multirow{2}{*}{,- 737} & \multirow{2}{*}{ 461 } \\
\hline & Erkek & 44 & 15,86 & 6,45 & & \\
\hline \multirow{2}{*}{ Performansı düşüren etkenler } & Kadın & 364 & 26,70 & 8,86 & \multirow{2}{*}{$-3,033$} & \multirow{2}{*}{,003 } \\
\hline & Erkek & 44 & 31,04 & 9,70 & & \\
\hline \multirow{2}{*}{ Okula karşı olumsuz tutum } & Kadın & 364 & 9,13 & 3,76 & \multirow{2}{*}{,- 789} & \multirow{2}{*}{,430 } \\
\hline & Erkek & 44 & 9,61 & 3,90 & & \\
\hline \multirow{2}{*}{$\begin{array}{l}\text { Çalışanların kararların alınmasına } \\
\text { katılımı }\end{array}$} & Kadın & 364 & 7,22 & 2,87 & \multirow{2}{*}{$-1,044$} & \multirow{2}{*}{,297 } \\
\hline & Erkek & 44 & 7,70 & 2,92 & & \\
\hline \multirow{2}{*}{ Toplam Sinizm } & Kadın & 364 & 58,26 & 16,66 & \multirow{2}{*}{$-2,216$} & \multirow{2}{*}{027} \\
\hline & Erkek & 44 & 64,22 & 18,33 & & \\
\hline
\end{tabular}

Tablo 3 incelendiğinde, çalıştkları kurumdan (Duyuşsal ve davranışsal) uzaklaşma boyutunda $\left(\mathrm{t}_{406}=-, 737, \mathrm{p}>.05\right)$, okula karşı olumsuz tutum boyutunda $\left(\mathrm{t}_{406}=-, 789, \mathrm{p}>.05\right)$ ve çalışanların kararların alınmasına katılımı boyutunda $\left(\mathrm{t}_{406}=-\right.$ $1,044, p>$.05) aradaki farkın anlamlı olmadığı bulunmuştur. Performansı düşüren etkenler boyutunda $\left(t_{406}=-3,033\right.$, $p<.05)$ ise aradaki farkın anlamlı olduğu bulunmuştur. Performansı düşüren etkenler boyutunda erkek okul öncesi öğretmenlerinin ortalamalarının ( $\bar{X}=31,04)$, kadın okul öncesi öğretmenlerin ortalamalarından $(\bar{X}=26,70)$ daha yüksek olduğu görülmektedir. Ayrıca, sinizm ölçeğinin genel toplamında $\left(\mathrm{t}_{406}=-2,216, \mathrm{p}<.05\right)$ da aradaki farkın anlamlı olduğu bulunmuştur. Sinizm ölçeğinin genel toplamında ise erkek okul öncesi öğretmenlerinin ortalamalarının $(\bar{X}=64,22)$, kadın okul öncesi öğretmenlerin ortalamalarından $(\bar{X}=58,26)$ daha yüksek olduğu görülmektedir.

\section{Okul öncesi öğretmenlerinin örgütsel sinizm tutumları yaşlarına göre farklılaşmakta mıdır?}

Okul öncesi öğretmenlerinin örgütsel sinizm tutumlarının yaşlarına göre farklılaşıp farklılaşmadığını belirlemek için yapılan Tek Faktörlü ANOVA sonucunda; okul öncesi öğretmenlerinin çalıştkları kurumdan (duyuşsal ve davranışsal) uzaklaşmaya ilişkin tutumlarının $\left(F_{404}=, 211, p>.05\right)$, performansı düşüren etkenlere ilişkin tutumlarının $\left(F_{404}=1,251, p>.05\right)$, okula karşı olumsuz tutumlarının $\left(F_{404}=, 992, p>.05\right)$, karar alınmasına katılımına ilişkin tutumlarının $\left(F_{404}=, 498, p>.05\right)$ ve sinizm ölçeğinin genel toplamında tutumlarının $\left(F_{404}=, 299, p>.05\right)$ anlamlı bir farklılık göstermediği bulunmuştur.

\section{Okul öncesi öğretmenlerinin örgütsel sinizm tutumları kıdemlerine göre farklılaşmakta mıdır?}

Okul öncesi öğretmenlerinin örgütsel sinizm tutumlarının kıdemlerine göre farklılaşıp farklılaşmadığını belirlemek için yapılan Tek Faktörlü ANOVA sonucunda; okul öncesi öğretmenlerinin çalıştkları kurumdan (duyuşsal ve davranışsal) uzaklaşmaya ilişkin tutumlarının $\left(F_{405}=1,737, p>.05\right)$, performansı düşüren etkenlere ilişkin tutumlarının $\left(F_{405}=3,045, p>.05\right)$, okula karşı olumsuz tutumlarının $\left(F_{405}=, 612, p>.05\right)$, karar alınmasına kathlımına ilişkin tutumlarının $\left(F_{405}=, 072, p>.05\right)$ ve sinizm ölçeğinin genel toplamında tutumlarının $\left(F_{405}=2,349, p>.05\right)$ anlamlı bir farklılık göstermediği bulunmuştur.

Okul öncesi öğretmenlerinin örgütsel sinizm tutumları öğrenim düzeylerine göre farklılaşmakta mıdır?

Tablo 4. Okul Öncesi Öğretmenlerinin Örgütsel Sinizm Ölçeği Puanlarının Öğrenim Düzeylerine Göre T Testi Sonuçları

\begin{tabular}{|c|c|c|c|c|c|c|}
\hline & $\begin{array}{l}\text { Öğrenim } \\
\text { Düzeyi }\end{array}$ & $\mathbf{N}$ & $\bar{x}$ & S.s & $\mathbf{t}$ & p \\
\hline \multirow{2}{*}{$\begin{array}{l}\text { Kurumdan (Duyuşsal ve davranış- } \\
\text { sal) uzaklaşma }\end{array}$} & Ön lisans & 70 & 16,68 & 5,70 & \multirow{2}{*}{2,314} & \multirow{2}{*}{,021 } \\
\hline & Lisans & 338 & 14,97 & 5,60 & & \\
\hline \multirow{2}{*}{ Performansı düşüren etkenler } & Ön lisans & 70 & 32,17 & 7,77 & \multirow{2}{*}{5,236} & \multirow{2}{*}{,000 } \\
\hline & Lisans & 338 & 26,14 & 8,96 & & \\
\hline \multirow{2}{*}{ Okula karşı olumsuz tutum } & Ön lisans & 70 & 9,41 & 4,04 & \multirow{2}{*}{,548 } & \multirow{2}{*}{,584 } \\
\hline & Lisans & 338 & 9,14 & 3,72 & & \\
\hline \multirow{2}{*}{$\begin{array}{l}\text { Çalışanların kararların alınmasına } \\
\text { katılımı }\end{array}$} & Ön lisans & 70 & 7,21 & 2,52 & \multirow{2}{*}{,- 200} & \multirow{2}{*}{,842 } \\
\hline & Lisans & 338 & 7,28 & 2,94 & & \\
\hline \multirow{2}{*}{ Toplam Sinizm } & Ön lisans & 70 & 65,48 & 16,65 & \multirow{2}{*}{3,623} & \multirow{2}{*}{,000 } \\
\hline & Lisans & 338 & 57,55 & 16,68 & & \\
\hline
\end{tabular}

| Kastamonu Eğitim Dergisi, 27(5), 2019 | 
Tablo 4 incelendiğinde; okula karşı olumsuz tutum boyutunda $(t 406=, 548, p>.05)$ ve çalışanların kararların alınmasına katlımı boyutunda (t406=-,200, p>.05) aradaki farkın anlamlı olmadığı bulunmuştur.

Performansı düşüren etkenler boyutunda $\left(t_{406}=5,236, p<.05\right)$ aradaki farkın anlamlı olduğu bulunmuştur. Performansı düşüren etkenler boyutunda ön lisans mezunu okul öncesi öğretmenlerinin ortalamalarının $(\bar{X}=32,17)$, lisans mezunu okul öncesi öğretmenlerin ortalamalarından $(\bar{X}=26,14)$ daha yüksek olduğu görülmektedir. Çalıştkları kurumdan (Duyuşsal ve davranışsal) uzaklaşma boyutunda $\left(\mathrm{t}_{406}=2,314, \mathrm{p}<.05\right)$ aradaki farkın anlamlı olduğu bulunmuştur. Çalıştkları kurumdan (Duyuşsal ve davranışsal) uzaklaşma boyutunda ön lisans mezunu okul öncesi öğretmenlerinin ortalamalarının $(\bar{X}=16,68)$, lisans mezunu okul öncesi öğretmenlerin ortalamalarından $(\bar{X}=14,97)$ daha yüksek olduğu görülmektedir. Ayrıca, sinizm ölçeğinin genel toplamında $\left(t_{406}=3,623, p<.05\right)$ okul öncesi öğretmenlerinin öğrenim düzeylerine göre anlamlı bir farklılık bulunmuştur. Sinizm ölçeğinin genel toplamında ön lisans mezunu okul öncesi öğretmenlerinin ortalamalarının $(\bar{X}=65,48)$, lisans mezunu okul öncesi öğretmenlerin ortalamalarından $(\bar{X}=57,55)$ daha yüksek olduğu görülmektedir.

Okul öncesi öğretmenlerinin örgütsel sinizm tutumları kurumdaki çalışma durumlarına göre farklılaşmakta mıdır?

Tablo 5. Okul Öncesi Öğretmenlerinin Örgütsel Sinizm Ölçeği Puanlarının Kurumdaki Çalışma Durumlarına Göre T Testi Sonuçları

\begin{tabular}{|c|c|c|c|c|c|c|}
\hline & $\begin{array}{l}\text { Çalışma } \\
\text { Durumu }\end{array}$ & $\mathbf{N}$ & $\bar{x}$ & S.s & $\mathbf{t}$ & $\mathbf{p}$ \\
\hline \multirow{2}{*}{$\begin{array}{l}\text { Kurumdan (Duyuşsal ve davranış- } \\
\text { sal) uzaklaşma }\end{array}$} & Kadrolu & 315 & 14,79 & 5,51 & \multirow{2}{*}{$-3,185$} & \multirow{2}{*}{,002 } \\
\hline & Ücretli & 93 & 16,89 & 5,85 & & \\
\hline \multirow{2}{*}{ Performansı düşüren etkenler } & Kadrolu & 315 & 26,01 & 8,82 & \multirow{2}{*}{$-4,886$} & \multirow{2}{*}{000} \\
\hline & Ücretli & 93 & 31,09 & 8,74 & & \\
\hline \multirow{2}{*}{ Okula karşı olumsuz tutum } & Kadrolu & 315 & 9,11 & 3,75 & \multirow{2}{*}{,- 732} & \multirow{2}{*}{,465 } \\
\hline & Ücretli & 93 & 9,44 & 3,88 & & \\
\hline \multirow{2}{*}{$\begin{array}{l}\text { Çalışanların kararların alınmasına } \\
\text { katılımı }\end{array}$} & Kadrolu & 315 & 7,30 & 2,91 & \multirow{2}{*}{,400 } & \multirow{2}{*}{,689 } \\
\hline & Ücretli & 93 & 7,17 & 2,74 & & \\
\hline \multirow{2}{*}{ Toplam Sinizm } & Kadrolu & 315 & 57,23 & 16,40 & \multirow{2}{*}{$-3,748$} & \multirow{2}{*}{,000 } \\
\hline & Ücretli & 93 & 64,60 & 17,52 & & \\
\hline
\end{tabular}

Tablo 5 incelendiğinde; çalıştıkları kurumdan (Duyuşsal ve davranışsal) uzaklaşma boyutunda $\left(\mathrm{t}_{406}=-3,185, \mathrm{p}<.05\right.$ ) aradaki farkın anlamlı olduğu bulunmuştur. Çalıştıkları kurumdan (Duyuşsal ve davranışsal) uzaklaşma boyutunda ücretli çalışan okul öncesi öğretmenlerinin ortalamalarının $(\bar{X}=16,89)$, kadrolu çalışan okul öncesi öğretmenlerin ortalamalarından $(\bar{X}=14,79)$ daha yüksek olduğu görülmektedir.

Performansı düşüren etkenler boyutunda $\left(t_{406}=-4,886, p<.05\right)$ çalışma durumuna göre anlamlı fark bulunmuştur. Performansı düşüren etkenler boyutunda ücretli olarak çalışan okul öncesi öğretmenlerinin ortalamalarının $(\bar{X}=31,09)$, kadrolu çalışan okul öncesi öğretmenlerin ortalamalarından $(\bar{X}=26,01)$ daha yüksek olduğu görülmektedir.

Sinizm ölçeğinin genel toplamında $\left(t_{406}=-3,748, p<.05\right)$ çalışma durumuna göre anlamlı fark bulunmuştur. Sinizm ölçeğinin genel toplamında ücretli olarak çalışan okul öncesi öğretmenlerinin ortalamalarının $(\bar{X}=64,60)$, kadrolu çalışan okul öncesi öğretmenlerin ortalamalarından $(\bar{X}=57,23)$ daha yüksek olduğu görülmektedir.

Okula karşı olumsuz tutum boyutunda $\left(\mathrm{t}_{406}=-, 732, \mathrm{p}>.05\right)$ ve çalışanların kararların alınmasına katılımı boyutunda $\left(t_{406}=, 400, p>.05\right)$ ise okul öncesi öğretmenlerinin çalışma durumlarına göre anlamlı bir fark bulunmamıştır.

\section{Okul öncesi öğretmenlerinin örgütsel sinizm tutumları eğitim verilen yaş grubuna göre farklılaşmakta mıdır?}

Okul öncesi öğretmenlerinin örgütsel sinizm tutumlarının eğitim verilen yaş grubuna göre farklılaşıp farklılaşmadığını belirlemek için yapılan Tek Faktörlü ANOVA sonucunda; okul öncesi öğretmenlerinin çalıştkları kurumdan (duyuşsal ve davranışsal) uzaklaşmaya ilişkin tutumlarının $\left(F_{404}=1,828, p>.05\right)$, performansı düşüren etkenlere ilişkin tutumlarının $\left(F_{404}=1,848, p>.05\right)$, okula karşı olumsuz tutumlarının $\left(F_{404}=, 405, p>.05\right)$, karar alınmasına katılımına ilişkin tutumlarının $\left(F_{404}=, 213, p>.05\right)$ ve sinizm ölçeğinin genel toplamında tutumlarının $\left(F_{404}=1,543, p>.05\right)$ anlamlı bir farklılık göstermediği bulunmuştur.

\section{Okul öncesi öğretmenlerinin örgütsel sinizm tutumları çalışılan kurum türüne göre farklılaşmakta mıdır?}

Okul öncesi öğretmenlerinin örgütsel sinizm tutumlarının çalışılan kurum türüne göre farklılaşıp farklılaşmadığını belirlemek için yapılan bağımsız örneklemler için t testi sonucunda; okul öncesi öğretmenlerinin çalıştkları kurumdan (duyuşsal ve davranışsal) uzaklaşmaya ilişkin tutumlarının $\left(t_{406}=, 176, p>.05\right)$, performansı düşüren etkenlere ilişkin tu- 
tumlarının $\left(\mathrm{t}_{406}=-, 229, \mathrm{p}<.05\right)$, okula karşı olumsuz tutumlarının $\left(\mathrm{t}_{406}=-, 566, \mathrm{p}>.05\right)$, karar alınmasına katılımına ilişkin tutumlarının $\left(t_{406}=-, 122, p>.05\right)$ ve sinizm ölçeğinin genel toplamında tutumlarının $\left(t_{406}=-, 211, p>.05\right)$ anlamlı bir farklılık göstermediği bulunmuştur.

Okul öncesi öğretmenlerinin örgütsel sinizm tutumları sınıftaki çocuk sayısına göre farklılaşmakta mıdır?

Tablo 6. Okul Öncesi Öğretmenlerinin Örgütsel Sinizm Tutumları Puanlarının Sınıftaki Çocuk Sayısına Göre Tek Faktörlü ANOVA Sonuçları

\begin{tabular}{|c|c|c|c|c|c|c|c|c|}
\hline & $\begin{array}{l}\text { Çocuk } \\
\text { sayısı }\end{array}$ & $\mathbf{N}$ & $\bar{x}$ & S.s. & Sd & $\mathbf{F}$ & $\mathbf{P}$ & $\begin{array}{c}\text { Anlamlı } \\
\text { Fark }\end{array}$ \\
\hline \multirow{4}{*}{$\begin{array}{l}\text { Kurumdan (Duyuşsal } \\
\text { ve davranışsal) uzak- } \\
\text { laşma }\end{array}$} & $11-15$ & 91 & 16,23 & 5,54 & \multirow{4}{*}{$3 / 404$} & \multirow{4}{*}{1,351} & \multirow{4}{*}{,257 } & \multirow{4}{*}{---} \\
\hline & $16-20$ & 163 & 14,85 & 5,63 & & & & \\
\hline & $21-25$ & 108 & 15,34 & 5,69 & & & & \\
\hline & $26-30$ & 46 & 14,67 & 5,77 & & & & \\
\hline \multirow{4}{*}{$\begin{array}{l}\text { Performansı düşüren } \\
\text { etkenler }\end{array}$} & $11-15$ & 91 & 29,64 & 9,30 & \multirow{4}{*}{$3 / 404$} & \multirow{4}{*}{3,086} & \multirow{4}{*}{,027 } & \multirow{4}{*}{$A-C$} \\
\hline & $16-20$ & 163 & 26,76 & 8,88 & & & & \\
\hline & $21-25$ & 108 & 26,10 & 8,22 & & & & \\
\hline & $26-30$ & 46 & 26,26 & 10,28 & & & & \\
\hline \multirow{4}{*}{$\begin{array}{l}\text { Okula karşı olumsuz } \\
\text { tutum }\end{array}$} & $11-15$ & 91 & 9,94 & 4,40 & \multirow{4}{*}{$3 / 404$} & \multirow{4}{*}{2,176} & \multirow{4}{*}{, 090 } & \multirow{4}{*}{---} \\
\hline & $16-20$ & 163 & 8,95 & 3,47 & & & & \\
\hline & $21-25$ & 108 & 8,72 & 3,83 & & & & \\
\hline & $26-30$ & 46 & 9,60 & 3,12 & & & & \\
\hline \multirow{4}{*}{$\begin{array}{l}\text { Çalışanların kararla- } \\
\text { rın alınmasına katılı- } \\
\text { mı }\end{array}$} & $11-15$ & 91 & 7,24 & 2,93 & \multirow{4}{*}{$3 / 404$} & \multirow{4}{*}{,958 } & \multirow{4}{*}{,413 } & \multirow{4}{*}{---} \\
\hline & $16-20$ & 163 & 7,09 & 2,69 & & & & \\
\hline & $21-25$ & 108 & 7,66 & 3,11 & & & & \\
\hline & $26-30$ & 46 & 7,06 & 2,82 & & & & \\
\hline \multirow{4}{*}{ Toplam Sinizm } & $11-15$ & 91 & 63,06 & 16,53 & \multirow{4}{*}{$3 / 404$} & \multirow{4}{*}{2,378} & \multirow{4}{*}{, 069 } & \multirow{4}{*}{--- } \\
\hline & $16-20$ & 163 & 57,67 & 16,41 & & & & \\
\hline & $21-25$ & 108 & 57,83 & 16,90 & & & & \\
\hline & $26-30$ & 46 & 57,60 & 18,69 & & & & \\
\hline
\end{tabular}

$A=11-15 \quad B=16-20 \quad C=21-25 \quad D=26-30$

Tablo 6 incelendiğinde; okul öncesi öğretmenlerinin çalıştıkları kurumdan (duyuşsal ve davranışsal) uzaklaşmaya ilişkin tutumlarının $\left(F_{404}=1,351, p>.05\right)$, okula karşı olumsuz tutumlarının $\left(F_{404}=2,176, p>.05\right)$, karar alınmasına katılımına ilişkin tutumlarının $\left(F_{404}=, 958, p>.05\right)$ ve sinizm ölçeğinin genel toplamında tutumlarının $\left(F_{404}=2,378, p>.05\right)$ anlamlı bir farklılık göstermediği bulunmuştur.

Okul öncesi öğretmenlerinin performansı düşüren etkenlere ilişkin tutumları ise anlamlı bir farklıık göstermiştir $\left(F_{404}=3,086, p<.05\right)$. Farkın hangi gruplar arasında olduğunu belirlemek için çoklu karşılaştırma testlerinden "Tukey" testi uygulanmış ve sınıflarında 11-15 aralığında çocuk bulunan okul öncesi öğretmenlerin performansı düşüren etkenlere ilişkin tutumlarının sınıflarında 21-25 aralığında çocuk bulunan öğretmenlerin tutumlarından anlamlı düzeyde farklılaşthğı bulunmuştur. Sınıflarında 11-15 aralığında çocuk bulunan okul öncesi öğretmenlerinin ortalamalarının $(\bar{X}=29,64)$ sınıflarında 21-25 aralığında çocuk bulunan öğretmenlerin ortalamalarından $(\bar{X}=26,10)$ yüksek olduğu görülmektedir.

Okul öncesi öğretmenlerinin mesleki tükenmişlik düzeyleri ile örgütsel sinizm tutumları arasında anlamlı bir ilişki var mıdır?

Tablo 7. Okul Öncesi Öğretmenlerinin Mesleki Tükenmişlik Düzeyleri İle Örgütsel Sinizm Tutumları Arasındaki iliş̧ki

\begin{tabular}{|c|c|c|c|c|c|c|c|c|}
\hline Değişkenler & 1 & 2 & 3 & 4 & 5 & 6 & 7 & 8 \\
\hline 1. Duygusal Tükenme & 1 &, $52^{* *}$ &,$- 41^{* *}$ &, $38^{* *}$ &, $10^{*}$ &, $28^{* *}$ &, $24^{* *}$ &, $28^{* *}$ \\
\hline 2. Duyarsızlaşma & & 1 &,$- 51^{* *}$ &, $38^{* *}$ &, $11^{* *}$ &, $31^{* *}$ &, $33^{* *}$ &, $31 * *$ \\
\hline 3. Kişisel Başarı & & & 1 &,$- 29^{* *}$ & ,02 &,$- 31^{* *}$ &,$- 30^{* *}$ &,$- 21^{* *}$ \\
\hline 4. Kurumdan Uzaklaşma & & & & 1 &, $54^{* *}$ &, $65^{* *}$ &, $56^{* *}$ & $87^{* *}$ \\
\hline 5. Performansı düşüren etkenler & & & & & 1 &, $32^{* *}$ &, $27^{* *}$ &, $83^{* *}$ \\
\hline 6. Okula karşı olumsuz tutum & & & & & & 1 &, $52^{* *}$ &, $70^{* *}$ \\
\hline 7. Kararların alınmasına katılım & & & & & & & 1 &, $62^{* *}$ \\
\hline 8. Toplam Sinizm & & & & & & & & 1 \\
\hline
\end{tabular}

|Kastamonu Eğitim Dergisi, 27(5), 2019| 
Okul öncesi öğretmenlerinin mesleki tükenmişlik düzeyleri ile örgütsel sinizm tutumları arasında bir ilişkinin olup olmadığını belirlemek için yapılan Pearson korelasyon analizi sonucunda;

Mesleki tükenmişliğin Duygusal Tükenme boyutu ile örgütsel sinizmin kurumdan uzaklaşma $(r=, 38, p<.01)$, performansı düşüren etkenler ( $r=, 10, p<.05)$, okula karşı olumsuz tutum $(r=, 28, p<.01)$, kararların alınmasına katlım $(r=, 24$, $p<.01)$ boyutları ve toplam sinizm $(r=, 28, p<.01)$ arasında pozitif yönde anlamlı bir iliş̧i bulunmuştur. Diğer bir ifadeyle, okul öncesi öğretmenlerinin duygusal tükenmişliklerinin artması durumunda örgütsel sinizm tutumlarının da artacağı söylenebilir.

Mesleki tükenmişliğin duyarsızlaşma boyutu ile örgütsel sinizmin kurumdan uzaklaşma $(r=, 38, p<.01)$, performansı düşüren etkenler $(r=, 11, p<.01)$, okula karşı olumsuz tutum $(r=, 31, p<.01)$, kararların alınmasına katılım $(r=, 33, p<.01)$ boyutları ve toplam sinizm $(r=, 31, p<.01)$ arasında pozitif yönde anlamlı bir ilişki bulunmuştur. Diğer bir ifadeyle, okul öncesi öğretmenlerinin mesleki duyarsızlaşmalarının artması durumunda örgütsel sinizm tutumlarının da artacağı söylenebilir.

Mesleki tükenmişliğin Kişisel Başarı boyutu ile örgütsel sinizmin kurumdan uzaklaşma $(r=-, 29, p<.01)$, okula karşı olumsuz tutum $(r=-, 31, p<.01)$, kararların alınmasına katlım $(r=-, 30, p<.01)$ boyutları ve toplam sinizm $(r=-, 21, p<.01)$ arasında negatif yönde anlamlı bir ilişki bulunmuştur. Diğer bir ifadeyle, okul öncesi öğretmenlerinin Kişisel Başarılarının artması durumunda örgütsel sinizm tutumlarının azalacağı söylenebilir. Mesleki tükenmişliğin Kişisel Başarı boyutu ile örgütsel sinizmin performansı düşüren etkenler $(r=, 02, p>.05)$ boyutu arasında ise bir ilişki bulunmamıştr.

\section{Tartışma}

Okul öncesi öğretmenlerinin mesleki tükenmişlik düzeyleri cinsiyetlerine göre anlamlı bir farklılık göstermemiştir. Bu bulgu Akman, Taşkın, Özden ve Çörtü (2010) tarafindan yapılan çalışmanın bulgularıyla paralellik göstermektedir. Akman, Taşkın, Özden ve Çörtü (2010) okul öncesi öğretmenlerinin tükenmişliklerini inceledikleri çalışmada kadın ve erkek okul öncesi öğretmenlerinin mesleki tükenmişliklerinin üç boyutta da anlamlı bir farklılık göstermediğini bulmuşlardır. Bu sonucun ortaya çıkmasında okul öncesi öğretmenlerinin aynı fiziki koşulları paylaşmalarının, aynı işi yapmalarının veya olumlu ve olumsuz benzer durumları yaşamalarının etkili olduğu düşünülmektedir.

Okul öncesi öğretmenlerinin mesleki tükenmişlik düzeyleri yaşlarına göre anlamlı bir farklıık göstermemiştir. Yapılan bazı çalışmalarda yaş değişkeninin okul öncesi öğretmenlerinin mesleki tükenmişlikleri üzerindeki etkisine ilişkin farklı sonuçlar bulunmuştur. Öztürk ve Deniz (2008) tarafindan yapılan çalışmada, okul öncesi öğretmenlerinin mesleki tükenmişlikleri Duygusal Tükenme boyutunda ve Kişisel Başarı boyutunda yaş değişkenine göre anlamlı bir farklııı göstermemişken, duyarsızlaşma boyutunda anlamlı bir farklılık göstermiştir. 26-30 yaş aralığındaki okul öncesi öğretmenlerinin duyarsızlaşma düzeyleri 41 ve üzeri yaş aralığındaki öğretmenlerden daha yüksek bulunmuştur. Metin ve Saçan (2017) yaptıkları çalışmada okul öncesi öğretmenlerinin mesleki tükenmişliğin Duygusal Tükenme ve duyarsızlaşma boyutlarında yaş değişkeninin anlamlı bir farklılık göstermediğini, Kişisel Başarı boyutunda ise anlamlı bir farklılık gösterdiğini bulmuşlardır. 35 yaş ve altındaki okul öncesi öğretmenlerinin 36-40 yaş aralığındaki öğretmenlerden daha fazla Kişisel Başarısızlık hissettikleri bulunmuştur. Daha önce yapılan çalışmalarda yaş değişkeninin mesleki tükenmişliğin bazı boyutlarında anlamlı bir farklılık gösterdiği, ancak bu çalışmada ise hiçbir boyutta anlamlı bir farklılık bulunmamıştır.

Okul öncesi öğretmenlerinin mesleki tükenmişlik düzeyleri kıdemlerine göre anlamlı bir farklılık göstermemiştir. Bu bulgu bir önceki yaş değişkenine ilişkin bulguyla paralellik göstermektedir. Bu çalışmada yaş değişkeninin mesleki tükenmişliği etkileyen bir faktör olmadığı bulunmuştur, dolayısıyla yaş ve kıdem arasındaki ilişki göz önünde bulundurulduğunda kıdem değişkeninin de anlamlı bir farklılık göstermemesi beklenen bir sonuçtur. Yapılan bazı çalışmalarda başka branşlardaki öğretmenlerin mesleki tükenmişlik düzeyleri kıdemlerine göre anlamlı bir farklılık göstermişken (Cinay, 2015; Çolakoğlu, 2014; Tunaboylu, 2015), bazı çalışmalarda anlamlı bir farklılık bulunmamıştır (Adiloğulları, 2013; Erkul, 2014; Çintiriz, 2016; Tunç, 2013). Ertürk (2012) okul öncesi öğretmenlerinin mesleki tükenmişliklerinin kıdemlerine göre anlamlı bir farklılık göstermediğini bulmuştur. Ertürk'ün bu bulgusu bu çalışmadaki bulguyu destekler niteliktedir.

Okul öncesi öğretmenlerinin mesleki tükenmişlik düzeyleri öğrenim düzeylerine göre anlamlı bir farklılık göstermiştir. Lisans mezunu okul öncesi öğretmenlerinin ön lisans mezunu okul öncesi öğretmenlerinden daha fazla mesleklerine karşı duyarsızlaşma yaşadıkları, daha fazla duygusal tükenmişlik yaşadıkları ve daha fazla Kişisel Başarısızık yaşadıkları bulunmuştur. Bu bulgu Öztürk ve Deniz' in çalışmalarıyla desteklenmektedir. Öztürk ve Deniz (2008) tarafindan yapılan çalışmada, lisans mezunu okul öncesi öğretmenlerinin mesleki tükenmişliğin duyarsızlaşma boyutunda ön lisans ve açık öğretim mezunu öğretmenlerden daha fazla duyarsızlaşma yaşadıkları bulunmuştur. Lisans mezunu okul öncesi öğretmenlerinin almış oldukları eğitimin etkisiyle ideal eğitim sunma gayretlerinin gerçek yaşam durumlarında karşılanmamasının onlarda daha fazla tükenmişliğe sebep olduğu düşünülmektedir. 
Okul öncesi öğretmenlerinin mesleki tükenmişlik düzeyleri kurumdaki çalışma durumlarına göre anlamlı bir farklıık göstermiştir. Kadrolu olarak çalışan okul öncesi öğretmenlerinin ücretli olarak çalışan okul öncesi öğretmenlerinden daha fazla duygusal tükenmişlik yaşadıkları, daha fazla mesleklerine karşı duyarsızlaşma yaşadıkları ve daha fazla Kişisel Başarısızlık yaşadıkları bulunmuştur. Bu durumun ortaya çıkmasında kadrolu olarak çalışan öğretmenlerin iş garantilerinin bulunmasının etkili olduğu düşünülmektedir. Kadrolu olarak çalışan öğretmenlerin iş garantilerinden dolayı zamanla mesleklerindeki verimin düşmüş olabileceği, kendilerini mesleki anlamda geliştirmeye kapatmalarının, yaptıkları işte alışkanIıklarının ön plana çıkmış olabilmesinin mesleki tükenmişliklerini arttırdığı düşünülmektedir.

Okul öncesi öğretmenlerinin mesleki tükenmişlik düzeyleri eğitim verilen yaş grubuna göre anlamlı bir farklılık göstermemiştir. Illgili alanyazın incelendiğinde okul öncesi öğretmenlerinin mesleki tükenmişliklerini eğitim verilen yaş grubuna göre inceleyen bir çalışmaya rastlanmamıştır. Bu çalışmada eğitim verilen yaş grubuna göre okul öncesi öğretmenlerinin mesleki tükenmişliklerinin anlamlı bir farklılık göstermesi beklenmesine rağmen, mevcut bulgu bu beklentinin tersi yöndedir. 3 yaş grubuna eğitim veren bir okul öncesi öğretmeninin 5 yaş grubuna eğitim veren bir okul öncesi öğretmeninden daha fazla tükenmişlik yaşaması beklenmiş olmasına rağmen, mevcut bulgu anlamlı bir farklılık olmadığı yönündedir. Uygulanmakta olan okul öncesi eğitim programı 35-72 ay yaş aralığındaki bütün çocuklar için uygun kazanım ve göstergeler içermektedir. Okul öncesi öğretmenleri sınıflarındaki çocukların yaş grubuna uygun kazanım ve göstergeler seçip uygun etkinlikler planladıklarından dolayı sınıflarındaki çocukların mutluluğunu sağladıkları ve buna bağlı olarak daha az problemle karşılaşmış olmalarından dolayı mesleki tükenmişliklerinin sınıflarındaki çocukların yaş grubuna göre anlamlı bir farklılık göstermediği düşünülmektedir.

Okul öncesi öğretmenlerinin mesleki tükenmişlik düzeyleri çalışılan kurum türüne göre anlamlı bir farklıık göstermemiştir. Bu bulgu Metin ve Saçan tarafindan yapılan çalışmanın bulgularıyla paralellik göstermektedir. Metin ve Saçan (2017) yaptıkları çalışmada okul öncesi öğretmenlerinin çalıştkları kurum türünün (Anaokulu-Anasınıfi) tükenmişliğin bütün boyutlarında anlamlı bir farklılık göstermediğini bulmuşlardır. Türkiye'de her ne kadar çalışılan kurum türünün anaokulu ve anasınıf olmasının imkanlar açısından bir çok farklılığı doğurması söz konusu olsa da, öğretmenlerin sahip oldukları bir çok hak, görev ve sorumlulukları kurum türüne göre ciddi bir farklılık göstermemektedir. Bu nedenle de okul öncesi öğretmenlerin mesleki tükenmişlikleri çalışılan kurum türüne göre anlamlı bir farklılık göstermemiştir.

Okul öncesi öğretmenlerinin mesleki tükenmişlik düzeyleri sınıflarındaki çocuk sayısına göre anlamlı bir farklılık göstermemiştir. Bu bulgu incelendiğinde, her ne kadar anlamlı bir fark bulunmamış olsa da sınıflarında 26-30 aralığında çocuk bulunan okul öncesi öğretmenlerinin tükenmişlik ortalamalarının sınıflarında daha az çocuk bulunan öğretmenlerin ortalamalarından daha yüksek olduğu bulunmuştur. Ayrıca, Metin ve Saçan (2017) yaptıkları çalışmada okul öncesi öğretmenlerinin sınıflarındaki çocuk sayısının tükenmişliğin Duygusal Tükenme boyutunda anlamlı bir farklılık gösterdiğini bulmuşlardır. Sınıflarında 12-20 aralığında çocuk bulunan öğretmenlerin mesleki tükenmişliklerinin, sınıflarında 21 ve yukarısında çocuk bulunan öğretmenlerin mesleki tükenmişliklerinden daha düşük olduğunu bulmuşlardır. Kalabalık sınıfların öğretmenlerin mesleki tükenmişliklerini artırdığı söylenebilir.

Okul öncesi öğretmenlerinin örgütsel sinizm tutumları cinsiyetlerine göre çalıştkları kurumdan (Duyuşsal ve davranışsal) uzaklaşma boyutunda, okula karşı olumsuz tutum boyutunda ve çalışanların kararların alınmasına katılımı boyutunda anlamlı bir farklıık göstermemiştir. Performansı düşüren etkenler boyutunda ve sinizm ölçeğinin genel toplamında ise erkek okul öncesi öğretmenlerinin kadın okul öncesi öğretmenlerinden daha olumsuz tutum sahibi oldukları bulunmuştur. Okul öncesi öğretmenleri kadınların baskın olarak çalıştkları bir meslektir. Türkiye'de 2017 yılı verilerine göre erkek okul öncesi öğretmenlerinin oranı \% 5.74'tür (MEB, 2017). Erkeklerin sayıca az oldukları bir meslekte kadın öğretmenlere kıyasla bir takım zorluklar yaşadıkları düşünülmektedir (Tezel-Şahin ve Sak, 2016; Sak ve Tezel-Şahin, 2012). Bu nedenle de erkek okul öncesi öğretmenlerinin örgütsel sinizm tutumlarının daha yüksek çıkması beklenen bir durumdur.

Okul öncesi öğretmenlerinin örgütsel sinizm tutumları ölçeğin bütün alt boyutlarında ve ölçeğin genel toplamında yaşlarına göre anlamlı bir farklılık göstermemiştir. İlgili alan yazında okul öncesi öğretmenlerinin örgütsel sinizm tutumlarını inceleyen bir çalışmaya rastlanmamıştr. Diğer kademelerdeki öğretmenlerin yaşlarına göre örgütsel sinizm tutumları bazı çalışmalarda anlamlı bir farklılık göstermişken (Amasralı, 2016; Karademir, 2016; Polat, 2014), bazı çalışmalarda anlamlı bir farklılık göstermemiştir (Bölükbaşığlu, 2013; Polatcan, 2012; Uzun, 2015; Yüksel, 2015).

Okul öncesi öğretmenlerinin örgütsel sinizm tutumları ölçeğin bütün alt boyutlarında ve ölçeğin genel toplamında kıdemlerine göre anlamlı bir farklılık göstermemiştir. İlgili alan yazında okul öncesi öğretmenlerinin örgütsel sinizm tutumlarını inceleyen bir çalışmaya rastlanmamıştır. Diğer kademelerdeki öğretmenlerin kıdemlerine göre örgütsel sinizm tutumları bazı çalışmalarda anlamlı bir farklılık göstermişken (Altınkurt ve Yılmaz, 2016; Amasralı, 2016; Karademir, 2016; Polat, 2014), bazı çalışmalarda anlamlı bir farklılık göstermemiştir (Polatcan, 2012; Uzun, 2015; Yüksel, 2015). Yaş ve kıdem arasında bir paralellik olduğu göz önünde bulundurulduğunda, diğer bir ifade ile yaşı büyük olan öğretmenlerin kıdemlerinin de daha fazla olduğu varsayıldığında, bu çalışmada hem yaş hem de kıdem değişkenlerinin anlamlı bir farklıık göster-

| Kastamonu Eğitim Dergisi, 27(5), 2019| 
memesi bir tutarlılık göstergesi olarak kabul edilebilir.

Okul öncesi öğretmenlerinin örgütsel sinizm tutumları öğrenim düzeylerine göre okula karşı olumsuz tutum boyutunda ve çalışanların kararların alınmasına katılımı boyutunda anlamlı bir farklılık göstermemiştir. Ancak, performansı düşüren etkenler boyutunda, çalıştkları kurumdan (duyuşsal ve davranışsal) uzaklaşma boyutunda ve sinizm ölçeğinin genel toplamında anlamlı bir farklılık bulunmuştur. Ön lisans mezunu okul öncesi öğretmenlerinin lisans mezunu okul öncesi öğretmenlerinden daha fazla performanslarını düşüren etkenlere ilişkin olumsuz tutum sahibi oldukları ve daha fazla çalıştıkları kurumdan uzaklaşma tutumuna sahibi oldukları bulunmuştur. Diğer kademelerde görev yapan öğretmenlere ilişkin yapılan bazı çalışmalarda öğrenim durumuna göre örgütsel sinizm tutumunun anlamlı bir farklılık gösterdiği (Polat, 2014), bazı çalışmalarda ise anlamlı bir farklılık göstermediği (Bölükbaşığlu, 2013; Uzun, 2015; Yüksel, 2015) bulunmuştur. Bu çalışmadaki, okul öncesi öğretmenlerinin performansı düşüren etkenler boyutunda, çalıştıkları kurumdan (duyuşsal ve davranışsal) uzaklaşma boyutunda ve sinizm ölçeğinin genel toplamındaki anlamlı farklılık incelendiğinde, ön lisans mezunu öğretmenlerin ortalamalarının lisans mezunu öğretmenlerin ortalamalarından daha yüksek olduğu görülmektedir. Son yıllarda Türkiye'de okul öncesi öğretmeni olarak atanabilmek için lisans mezunu olmak gerekmektedir. Dolayısıyla ön lisans mezunu olarak çalışan okul öncesi öğretmenleri öğrenim düzeylerinden kaynaklı bir yetersizlik veya çalıştkları kurumlarda kendilerinin ön lisans mezunu olmalarından kaynaklı bir takım olumsuzluklar yaşama ihtimallerinin bu sonucu etkilediği düşünülmektedir.

Okul öncesi öğretmenlerinin örgütsel sinizm tutumları kurumdaki çalışma durumuna göre okula karşı olumsuz tutum boyutunda ve çalışanların kararların alınmasına katılımı boyutunda anlamlı bir farklıık göstermemiştir. Ancak, çalıştıkları kurumdan (duyuşsal ve davranışsal) uzaklaşma boyutunda, performansı düşüren etkenler boyutunda ve sinizm ölçeğinin genel toplamında anlamlı bir farklıık bulunmuştur. Ücretli olarak çalışan okul öncesi öğretmenlerinin kadrolu olarak çalışan okul öncesi öğretmenlerinden daha fazla çalıştıkları kurumdan (duyuşsal ve davranışsal) uzaklaşmaya ilişkin olumsuz tutuma sahip oldukları bulunmuştur. Ücretli olarak çalışan okul öncesi öğretmenlerinin kadrolu olarak çalışan okul öncesi öğretmenlerinden daha fazla performanslarını düşüren etkenlere ilişkin olumsuz tutuma sahip oldukları bulunmuştur. Bu bulgu Yayla, Sak, Şahin Sak ve Taşkın tarafindan yapılan çalışmanın bulgularıyla paralellik göstermektedir. Yayla, Sak, Şahin Sak ve Taşkın (2017) yaptıkları çalışmada kadrolu ve ücretli olarak çalışan okul öncesi öğretmenlerinin mesleki doyumları arasında anlamlı farklılıklar olduğunu, ücretli olarak çalışan okul öncesi öğretmenlerinin mesleki doyumlarının daha düşük olduğu ve katılımcıların ücretli olarak çalışmanın bazı dezavantajları olduğunu belirttiklerini bulmuşlardır. Ücretli olarak çalışan okul öncesi öğretmenleri kadrolu olarak çalışan okul öncesi öğretmenleriyle aynı işi yapmalarına rağmen, aldıkları ücret çok daha düşük, birçok sosyal haktan mahrum olmakla birlikte çoğu zaman okul yönetimi, diğer öğretmenler ve veliler tarafindan öğretmen olarak kabul edilmemektedirler (Yayla, Sak, Şahin Sak ve Taşkın, 2017). Bu nedenle ücretli olarak çalışan okul öncesi öğretmenlerinin örgütsel sinizm tutumlarının daha olumsuz olması beklenen bir sonuçtur.

Okul öncesi öğretmenlerinin örgütsel sinizm tutumları ölçeğin bütün alt boyutlarında ve ölçeğin genel toplamında eğitim verdikleri yaş grubuna göre anlamlı bir farklılık göstermemiştir. Eğitim verilen yaş grubu değişkeni her ne kadar öğretmenin sınıf içi ve sınıf dışı uygulamalarını etkilese de, bu sonuç yaş grubu değişkeninin okul öncesi öğretmenlerinin örgütsel sinizm tutumlarını etkileyen bir değişken olmadığı şeklinde yorumlanabilir.

Okul öncesi öğretmenlerinin örgütsel sinizm tutumları ölçeğin bütün alt boyutlarında ve ölçeğin genel toplamında çalıştkkları kurum türüne göre anlamlı bir farklıık göstermemiştir. Okul öncesi öğretmenlerinin görev yaptikları anaokulu ve anasınıf arasında bir takım farklılıklar bulunmaktadır. Anaokullarında çalışmanın anasınıflarında çalışmayla karşılaştrıldığında bir takım avantajlarının olduğu düşünülmektedir. Özellikle ilkokulların bünyesindeki anasınıfları okul yönetimleri tarafindan yeterince önemsenmemekte, anasınıflarının birçok talepleri ikinci plana itilmektedir. Bu sebeplerden dolayı anaokulu veya anasınıfinda çalışmanın okul öncesi öğretmenlerinin örgütsel sinizm tutumlarını etkileyen bir faktör olması beklenmesine rağmen, bu çalışmada anlamlı bir farklılık bulunmamıştır.

Okul öncesi öğretmenlerinin örgütsel sinizm tutumları sınıflarındaki çocuk sayısına göre çalıştkları kurumdan (duyuşsal ve davranışsal) uzaklaşma boyutunda, okula karşı olumsuz tutum boyutunda, çalışanların kararların alınmasına katılımı boyutunda ve sinizm ölçeğinin genel toplamında anlamlı bir farklılık göstermemiştir. Ancak, performansı düşüren etkenler boyutunda anlamlı bir farklılık bulunmuştur. Sınıflarında 11-15 aralığında çocuk bulunan okul öncesi öğretmenlerinin, sınıflarında 21-25 aralığında çocuk bulunan öğretmenlerden daha fazla performanslarını düşüren etkenlere ilişkin olumsuz tutuma sahip oldukları bulunmuştur. Okul öncesi eğitim kurumlarında öğretmenler gün boyunca oyun, sanat, müzik, drama, Türkçe, matematik, fen, hareket ve alan gezisi gibi farklı etkinlikler planlayıp uygulamaktadırlar. Diğer eğitim kademelerinde her ne kadar çocuk sayısının azlığı tercih edilse de okul öncesi eğitim kurumlarında çocuk sayısının özellikle 15 'in altında olması bazı etkinliklerin (oyun, drama, hareket) amacına ulaşmasını ve keyif alınmasını engellemektedir. Bu bulgunun ortaya çıkmasında okul öncesi öğretmenlerinin daha iyi bir performans için sınıflarında 21-25 aralığında çocuk olmasını tercih etmelerinin etkili olduğu düşünülmektedir. 
Mesleki tükenmişliğin Duygusal Tükenme boyutu ve duyarsızlaşma boyutu ile örgütsel sinizmin bütün boyutları ve toplam sinizm arasında pozitif yönde anlamlı bir ilişki bulunmuştur. Mesleki tükenmişliğin Kişisel Başarı boyutu ile örgütsel sinizmin kurumdan uzaklaşma, okula karşı olumsuz tutum, kararların alınmasına katılım boyutları ve toplam sinizm arasında negatif yönde anlamlı bir ilişki bulunmuştur. Mesleki tükenmişliğin Kişisel Başarı boyutu ile örgütsel sinizmin performansı düşüren etkenler boyutu arasında ise bir ilişki bulunmamıştır. Mesleki tükenmişlik ile örgütsel sinizm tutumu arasındaki ilişkiye ait bu bulgu Amasralı'nın çalışmasıyla paralellik göstermektedir. Amasralı (2016) öğretmenlerin bilişsel, davranışsal ve duyuşsal sinizm tutumları ile mesleki tükenmişliğin Duygusal Tükenme ve duyarsızlaşma boyutları arasında pozitif, Kişisel Başarı boyutu arasında ise negatif yönlü bir ilişki olduğu bulunmuştur. Mesleki tükenmişlik ile örgütsel sinizm tutumu arasındaki ilişkiye ait bulgular genel itibariyle beklenen bulgular olup, mesleki tükenmişliğin artması durumunda örgütsel sinizm tutumunun da arttğı söylenebilir. Ayrıca, bu bulgu Simbula ve Guglielmi'nin (2010) sinizmin öğretmenlerin mesleki tükenmişliklerinin bir boyutu olarak ele alınabileceğine ilişkin sonuçlarıyla da örtüşmektedir.

\section{Sonuç ve Öneriler}

Sonuç olarak, okul öncesi öğretmenlerinin mesleki tükenmişlik düzeyleri cinsiyetlerine, yaşlarına, kıdemlerine, eğitim verilen yaş grubuna, sınıflarındaki çocuk sayısına ve çalışılan kurum türüne göre anlamlı bir farklılık göstermemiştir. Öğrenim düzeylerine ve kurumdaki çalışma durumlarına göre ise anlamlı bir farklılık bulunmuştur. Okul öncesi öğretmenlerinin örgütsel sinizm tutumları ölçeğin bütün alt boyutlarında ve ölçeğin genel toplamında yaşlarına, eğitim verdikleri yaş grubuna, çalıştkları kurum türüne ve kıdemlerine göre anlamlı bir farklılık göstermemiştir. Ancak, cinsiyetlerine göre sinizm ölçeğinin genel toplamında ve performansı düşüren etkenler alt boyutunda anlamlı bir farklılık göstermiştir. Ayrıca öğretmenlerin tutumlarının, öğrenim düzeylerine ve kurumdaki çalışma durumuna göre performansı düşüren etkenler boyutunda, çalıştkları kurumdan uzaklaşma boyutunda ve sinizm ölçeğinin genel toplamında anlamlı bir farklıık gösterdiği bulunmuştur. Bununla birlikte, öğretmenlerin örgütsel sinizm tutumları sınıflarındaki çocuk sayısına göre performansı düşüren etkenler boyutunda anlamlı bir farklılık göstermiştir.

Mesleki tükenmişliğin Duygusal Tükenme boyutu ve duyarsızlaşma boyutu ile örgütsel sinizmin kurumdan uzaklaşma, performansı düşüren etkenler, okula karşı olumsuz tutum, kararların alınmasına katılım boyutları ve toplam sinizm arasında pozitif yönde anlamlı bir ilişki bulunmuştur. Mesleki tükenmişliğin Kişisel Başarı boyutu ile örgütsel sinizmin kurumdan uzaklaşma, okula karşı olumsuz tutum, kararların alınmasına katlım boyutları ve toplam sinizm arasında negatif yönde anlamlı bir ilişki bulunmuştur. Mesleki tükenmişliğin Kişisel Başarı boyutu ile örgütsel sinizmin performansı düşüren etkenler boyutu arasında ise bir ilişki bulunmamıştır.

Bu sonuçlar göz önünde bulundurulduğunda, okul öncesi öğretmenlerinin mesleki tükenmişlik düzeylerinin azaltılması ve örgütsel sinizm tutumlarının iyileştirilmesi için;

- Okul içerisinde idareci-öğretmen-veli arasında açık ve sağlıklı bir iletişime imkan verilebilir.

- Okulda herkes fikirlerini rahatça paylaşmak konusunda cesaretlendirilebilir.

- Tükenmişlikle baş etme yolları ve örgütsel bağlııkla ilgili eğitimler verilerek, öğretmenler, idareciler ve diğer okul çalışanları bilgilendirilebilir.

- Öğretmenlerin motivasyonlarını ve örgütsel bağlııklarını artırmak için gerek sınıf ortamlarında, gerekse dinlenme zamanlarını geçirecekleri mekânlarda düzenleme ve iyileştirmeler yapılabilir.

- Öğretmenlerden okulun fiziksel şartlarına (çocuk sayısı, okul donanımı, materyal gibi) uygun beklentilerde bulunulabilir.

- Öğretmenlerin yapmış olduğu başarılı işler ve gösterdiği çabalar takdir edilebilir.

- Hem sorumlulukların dağılımında hem de yapılan işlerin ödüllendirilmesinde adil olunabilir.

- Bundan sonra yapılacak başka çalışmalarda ise;

- Yalnızca Van veya Doğu Anadolu bölgesinde değil, daha büyükörneklemle Türkiye'de okul öncesi öğretmenlerinin mesleki tükenmişlikleri ile örgütsel sinizm tutumları arasındaki ilişki incelenebilir.

- Okul öncesi öğretmenlerinin mesleki tükenmişlikleri ve örgütsel sinizm tutumlarının nedenlerini ortaya koyacak nitel desende çalışmalar yapılabilir.

- Karma çalışma deseni kullanılarak öğretmenlerin tükenmişlikleri ve örgütsel sinizm tutumları, görüşmeler, gözlemler ve ölçek uygulamaları ile derinlemesine incelenebilir.

\section{Kaynakça}

Acar, F. M. (2016). Okul öncesi öğretmenlerinin tükenmişlik ve iş doyumu düzeylerinin bazı değişkenler açısından incelenmesi. Yayınlanmamış yüksek lisans tezi, Çağ Üniversitesi, Mersin. 
Adiloğulları, G. E. (2013). Beden eğitimi öğretmenlerinin duygusal zeka ile mesleki tükenmişlik düzeyleri arasındaki ilişkinin incelenmesi. Yayınlanmamış yüksek lisans tezi, Kahramanmaraş Sütçü İmam Üniversitesi, Kahramanmaraş.

Akduman, G. G. (2012). Okul öncesi eğitimin tanımı ve önemi (Editör: G. U. Balat). Okul öncesi eğitime giriş. Ankara: Pegem Akademi.

Akman, B., Taşkın, N., Özden, Z., ve Çörtü, F. (2010). A study on preschool teachers' burnout. Elementary Education Online, 9(2), 807-815.

Altınkurt, Y., ve Yılmaz, K. (2016). Öğretmenlerin mizah tarzları ile örgütsel sinizm düzeyleri arasındaki ilişki. Sakarya Üniversitesi Eğitim Fakültesi Dergisi, 32, 122-143.

Amasralı, A. (2016). Ortaokul ve lise matematik öğretmenlerinin örgütsel sinizm tutumları ile mesleki tükenmişlik düzeyleri arasındaki ilişki (Amasya illi Örneği). Yayınlanmamış yüksek lisans tezi, Ondokuz Mayıs Üniversitesi, Samsun.

Atmaca, T. (2014). Okul yöneticilerinin kullandıkları güç türleri ile öğretmenlerin yaşadıkları yıldırma, örgütsel bağlıık ve örgütsel sinizm arasındaki ilişki. Yayınlanmamış yüksek lisans tezi, Gazi Üniversitesi, Ankara.

Bölükbaşığlu, K. (2013). Öğretmenlerin örgütsel adalet algıları ile örgütsel sinizm tutumları arasındaki ilişki. Yayınlanmamış yüksek lisans tezi, Pamukkale Üniversitesi, Denizli.

Büyüköztürk, Ş., Çakmak, E., Akgün, Ö. E., Karadeniz, Ş., ve Demirel, F. (2014). Bilimsel araştırma yöntemleri. (17. Baskı). Ankara: Pegem Akademi Yayıncılık.

Can, A. (2016). SPSS ile bilimsel araştırma sürecinde nicel veri analizi. Ankara: Pegem Akademi Yayıncılık.

Chan, D. W. (2003). Hardiness and its role in the stress-burnout relationship among prospective teachers in Hong Kong. Teacher and Teacher Education, 19, 381-395.

Chaplain, R. P. (2008). Stress and psychological distress among trainee secondary teachers in England. Educational Psychology, 28, 195-209.

Cherniss, C. (1980). Staff burn-out: Job stress in the human services. Beverly Hills, California: Sage Publications.

Cinay, F. (2015). Illkokul öğretmenlerinin mesleki tükenmişlik düzeyleri ile örgütsel vatandaşlık davranışları arasındaki ilişki. Yayınlanmamış yüksek lisans tezi, Okan Üniversitesi, İstanbul.

Çalışkan, K. (2016). Spor eğitimi veren yükseköğretim kurumlarındaki öğretim elemanlarının örgütsel sinizm algıları ile örgütsel bağıııklarının araştırılması. Yayınlanmamış yüksek lisans tezi, Muğla Sıtkı Koçman Üniversitesi, Muğla.

Çanak, M. (2014). Okul yöneticilerinin örgütsel bağlııkları ile örgütsel sinizmleri arasındaki ilişki. Yayınlanmamış yüksek lisans tezi, Erciyes Üniversitesi, Kayseri.

Çintiriz, Ş. (2016). Mesleki ve Teknik Anadolu Liselerinde kültür dersi öğretmenlerinin mesleki tükenmişlik düzeyinin tespiti: Beşiktaş ilçesi örneği. Yayınlanmamış yüksek lisans tezi, İstanbul Aydın Üniversitesi, İstanbul.

Çolakoğlu, ì. (2014). Ortaokullarda görev yapan müzik öğretmenlerinin mesleki tükenmişlik düzeylerinin incelenmesi. Yayınlanmamış yüksek lisans tezi, İstanbul Aydın Üniversitesi ve Yıldız Teknik Üniversitesi, İstanbul.

Dean, J. W., Brandes, J. P., ve Dharwadkar, R. (1998). Organizational cynicism. The Academy of Management Review, 23(2), 341352.

Demirel, (2015). Öğretmen algılarına göre okul müdürlerinin toksik liderlik davranışları ile öğretmenlerin örgütsel sinizm tutumları arasındaki ilişki. (Gaziantep Şehitkamil ilçesi örneği). Yayınlanmamış yüksek lisans tezi, Zirve Üniversitesi, Gaziantep.

Deniz Kan, Ü. (2008). Bir Grup Okul Öncesi Öğretmeninde Tükenmişlik Durumunun İncelenmesi. Kastamonu Eğitim Dergisi, 16(2), 431-438.

Devilly, G. J., Wright, R. ve Varker, T. (2009). Vicarious trauma, secondary traumatic stress or simply burnout effect of trauma therapy on mental health professionals. Australian and New Zealand Journal of Psychiatry, 43, 373-385.

Ergen, S. (2015). Öğretmenlerin örgütsel sinizm düzeyleri ile örgütsel bağlılıkları arasındaki ilişki. Yayınlanmamış yüksek lisans tezi, Gazi Üniversitesi, Ankara.

Ergin, C. (1995). Akademisyenlerde tükenmişlik ve çeşitli stres kaynaklarının incelenmesi. Hacettepe Üniversitesi Edebiyat Fakültesi Dergisi, 12(1-2), 37-50.

Ertürk, M. (2012). Özel ve devlet okullarında çalışan okul öncesi öğretmenlerin demografik değişkenlere bağlı olarak mesleki tükenmişlik ve anksiyete düzeylerinin karşılaştırılması. Yayınlanmamış yüksek lisans tezi, Maltepe Üniversitesi, İstanbul.

Essa, E. L. (2013). Introduction to early childhood education. Belmont: Wardsworth.

Freudenberger, H. J. (1974). Staff burn-out. Journal of Social Issues, 30(1), 159-165.

Gün, F., ve Atanur Baskan, G. (2017). Öğretim elemanlarının algılarına göre örgütsel sinizm ile tükenmişlik düzeyleri arasındaki ilişkinin incelenmesi. Hacettepe Üniversitesi Eğitim Fakültesi Dergisi, 32(2), 361-379.

Gürbüz, Z. (2008). Kars ilinde görevli okul öncesi öğretmenlerinin iş tatmin düzeyleri ve mesleki tükenmişlik düzeylerinin incelenmesi. Yayımlanmamış Yüksek Lisans Tezi. Marmara Üniversitesi, İstanbul.

İnce, N. B. (2014). Birleştirilmiş ve bağımsız sınıf öğretmenlerinin mesleki doyum ve tükenmişlik düzeylerinin karşılaştırılması. Yayınlanmamış yüksek lisans tezi, Hacettepe Üniversitesi, Ankara. 
İnce, N. B., ve Şahin, A. E. (2015). Maslach Tükenmişlik Envanteri-Eğitimci Formunu Türkçe 'ye uyarlama çalışması. Eğitimde ve Psikolojide Ölçme ve Değerlendirme Dergisi, 6(2), 385-399.

Kapıkıran, A. (2003). Okul öncesi öğretmenlerde tükenmişliğin bazı değişkenler açısından incelenmesi. Eğitim Araştırmaları Dergisi, 4(13), 73-78.

Karadağ, E., Kılıçoğlu, G., ve Yılmaz, D. (2014). Örgütsel sinizm, okul kültürü ve okul başarısı: Bir yapısal eşitlik modelleme çalışması, Kuram ve Uygulamada Eğitim Bilimleri, 14(1), 89-113.

Karademir, M. (2016). Ortaokul öğretmenlerinin okul yönetiminde kayırmacılık algıları ile örgütsel sinizm arasındaki ilişkinin incelenmesi: İstanbul ili Pendik ilçesi örneği. Yayınlanmamış yüksek lisans tezi, İstanbul Aydın Üniversitesi, İstanbul.

Karasar, N. (2005). Bilimsel araştırma yöntemi. (14. Baskı). Ankara: Nobel Yayınevi.

Kılıç, M. (2013). Illköğretim okullarında görevli öğretmenlerin örgütsel sinizm düzeyleri ile iş doyumları arasındaki ilişkinin incelenmesi. Yayınlanmamış yüksek lisans tezi, Gaziantep Üniversitesi, Gaziantep.

Kılıç, Ş. (2011). Illköğretim okulu öğretmenlerinin örgütsel sinizm ve örgütsel bağlılık düzeyleri arasındaki ilişki (Keçiören ilçesi örneği). Yayınlanmamış yüksek lisans tezi, Hacettepe Üniversitesi, Ankara.

Koç, M. (2015). ilköğretim öğretmenlerinin tükenmişlik düzeyleri ile sinizm arasındaki ilişki (Ağrı ili, Patnos ilçesi örneği). Yayınlanmamış yüksek lisans tezi, Yeditepe Üniversitesi, İstanbul.

Koçyiğit, S. (2012). Okul öncesi eğitim kurumlarında personel. (Editör: G. U. Balat). Okul öncesi eğitime giriş. Ankara: Pegem Akademi.

Kutanis R. Ö., ve Dikili, A. (2010). Değişim boyutunda örgütlerde sinizm. D. E. Özler (Ed.), Örgütsel Davranışta Güncel Konular İçinde, 269-285. Bursa: Ekin Basım Yayın Dağıtım.

Lorente, L., Salanova, M., Martinez, I., \& Schaufeli, W. B. (2008). Extension of the Job Demands Resources model in the prediction of burnout and engagement among teachers over time. Psycothema, 20, 354-360.

Maslach, C. (2003). Job burnout new directions in research and intervention. Current Directions in Psychological Science, 12(5), 189-192.

Maslach, C. (2006). Stress and burnout. In A. M. Rossi, P. L. Perreve and S. L. Sauter (Eds.) Stress and quality of working life. International Stress Management Association.

Maslach, C., ve Jackson, S. E. (1981). The measurement of experienced burnout. Journal of Organizational Behavior, 2(2), 99-113.

Maslach, C., Schaufeli, W. B., ve Leiter, M. P. (2001). Job burnout. Annual Review of Psychology, 52, 397-422.

MEB (Ministry of National Education). (2017). National Education Statistics-2016-2017. Ankara: Ministry of National Education.

Metin, Ş., ve Saçan, S. (2017). An analysis of the effects of pre-school teachers' burnout levels on job satisfaction. International Journal of Family, Child and Education, 11, 44-67.

Montgomery, C., \& Rupp, A. A. (2005). Meta-analysis for exploring the diverse causes and

effects of stress in teachers. Canadian Journal of Education, 28, 458-486.

Morrison, G. S. (2011). Early childhood education today. Upper Saddle River, N.J: Merrill/Prentice Hall.

Özcan (2014). Öğretmenlerin örgütsel adalet algıları ile örgütsel sinizm tutumları arasındaki ilişki. Yayınlanmamış yüksek lisans tezi, Kocaeli Üniversitesi, Kocaeli.

Özer, S. (2014). Örgütsel sinizmin ve liderlik stillerinin sınıf öğretmenlerinin kuruma bağlılığına etkisi: (Adıyaman/Kahta ilçesi örneği). Yayınlanmamış yüksek lisans tezi, Zirve Üniversitesi, Gaziantep.

Öztürk, A., ve Deniz, M. E. (2008). Analysis of emotional intelligence job satisfaction and burnout levels of preschool teachers according to some variables. Ilköğretim Online, 7(3), 578-599.

Polat, E. Ç. (2014). Kurum içi etkin iletişim ortamı ile örgütsel sinizm arasındaki ilişki: Öğretmenlerin görüşleri açısından incelenmesi. Yayınlanmamış yüksek lisans tezi, Erciyes Üniversitesi, Kayseri.

Polatcan, M. (2012). Okul yöneticilerinin liderlik davranışları ile öğretmenlerin örgütsel sinizm tutumları arasındaki ilişki (Karabük ili örneği). Yayınlanmamış yüksek lisans tezi, Sakarya Üniversitesi, Sakarya.

Sağır, T., ve Oğuz, E.. (2012). Öğretmenlere yönelik örgütsel sinizm ölçeğinin geliştirilmesi. International Journal of Human Sciences, 9(2), 1094-1106.

Sak, R., \& Tezel-Şahin, F. (2012). Analysis of male preschool teachers' thoughts regarding their careers. International Journal of Early Childhood Education, 18 (1), 73-93.

Salanova, M., Llorens, S., Garcia-Renedo, M., Burriel, R., Bresó, E., \& Schaufeli, W. B. (2005). Toward a four-dimensional model of burnout: A multigroup factor-analytic study including depersonalization and cynicism. Educational and Psychological Measurement, 65, 901-913.

Sandıkçı, E. (2010). Stresin tükenmişlik boyutları üzerindeki etkisi: Diyarbakır'da öğretmenler üzerinde bir araştırma. Yayınlanmamış yüksek lisans tezi. Erciyes Üniversitesi, Kayseri.

Simbula, S., ve Guglielmi, D. (2010). Depersonalization or cynicism, efficacy or inefficacy: What

are the dimensions of teacher burnout? European Journal of Psychology of Education, 25(3), 301-314. 
Şenel, E., ve Buluş, M. (2016). Okul öncesi öğretmenlerinde tükenmişlik döngüsü ve tükenmişlik döngüsünde öz yeterliğin aracılık rolü. Buca Eğitim Fakültesi Dergisi, 42, 1-23.

Şirin, E. (2011). ilköğretim okullarındaki öğretmenlerin okul kültürü algıları ile örgütsel sinizm tutumları arasındaki ilişki (İstanbul ili, Esenyurt ilçesi örneği). Yayınlanmamış yüksek lisans tezi, Yeditepe Üniversitesi, İstanbul.

Tezel-Şahin, F., ve Sak, R. (2016). A comparative study of male and female early childhood teachers' job satisfaction in Turkey. Early Childhood Education Journal, 44, 473-481 Doi: 10.1007/s10643-015-0738-x (ERIC)

Tunaboylu, M. (2015). illkokul ve ortaokul öğretmenlerinin mesleki tükenmişlik düzeyleri (İzmir ili Torbalı ilçesi örneği). Yayınlanmamış yüksek lisans tezi, Okan Üniversitesi, İzmir.

Tunç, V. (2013). Tarih öğretmenlerinin iş doyum ve mesleki tükenmişlik düzeylerinin bazı değişkenler açısından incelenmesi: Van ili örneği. Yayınlanmamış yüksek lisans tezi, Yüzüncü Yıl Üniversitesi, Van.

Tuğrul, B., ve Çelik, E. (2002). Normal çocuklarla çalışan anaokulu öğretmenlerinde tükenmişlik. Pamukkale Üniversitesi Eğitim Fakültesi Dergisi, 2(12), 1-11.

Uzun, T. (2015). Okul müdürlerinin iletişim becerileri ile öğretmenlerin genel ve örgütsel sinizm tutumları arasındaki ilişkilerin incelenmesi (Giresun ili örneği). Yayınlanmamış doktora tezi, Atatürk Üniversitesi, Erzurum.

Yalçın, S. (2013). ilköğretim okulu öğretmenlerinin mesleki tükenmişlik düzeyleri ile stres, psikolojik dayanıklılık ve akademik iyimserlik arasındaki ilişki. Yayınlanmamış yüksek lisans tezi, Gazi Üniversitesi, Ankara.

Yalçın, U. (2017). Araştırma görevlilerinin örgütsel sinizm algılarının işten ayrılma niyetine etkisi. Yayınlanmamış yüksek lisans tezi, Atatürk Üniversitesi, Ankara.

Yaşar Ekici, F. (2017). Mesleki Tükenmişlik Açısından Okul Öncesi Öğretmenlerinin Değerlendirilmesi. Anemon Muş Alparslan Üniversitesi Sosyal Bilimler Dergisi, 5(2), 425-446.

Yayla, A., Sak, R., Şahin Sak, I. T., ve Taşkın, N. (2017). Comparing the job satisfaction of hourly paid and salaried preschool teachers in Turkey. Education 3-13. doi.org/10.1080/03004279.2017.1365919

Yıldırım, G. (2015). Lise öğretmenlerinin örgütsel sinizm tutumları ile örgütsel vatandaşlık davranışları arasındaki ilişki. Yayınlanmamış yüksek lisans tezi, Gazi Üniversitesi, Ankara.

Yıldız, M. ve Uzum, P.A. (2018). Okul Öncesi Öğretmenlerinin Tükenmişlik Düzeylerinin Sınıf Yönetimi Becerileri ile i̇lişkisi. Akdeniz Eğitim Araştırmaları Dergisi, 12(24), 156-174.

Yüksel, H. (2015). Örgütsel sinizm ve bağlılık arasındaki ilişki: ilk ve ortaokul öğretmenleri üzerinde bir araştırma. Yayınlanmamış yüksek lisans tezi, Dokuz Eylül Üniversitesi, İzmir. 